(Revised manuscript)

\title{
Metal-catalyzed nitrile hydration reactions: The specific contribution of ruthenium
}

\author{
Rocío García-Álvarez, Javier Francos, Eder Tomás-Mendivil, Pascale Crochet and
} Victorio Cadierno*

Laboratorio de Compuestos Organometálicos y Catálisis (Unidad Asociada al CSIC), Departamento de Química Orgánica e Inorgánica, Instituto Universitario de Química Organometálica "Enrique Moles”, Universidad de Oviedo, Julián Clavería 8, 33006 Oviedo, Spain

*Corresponding author. E-mail address: vcm@uniovi.es (V. Cadierno) 


\begin{abstract}
The hydration of nitriles is an atom economical route to generate primary amides of great academic and industrial significance. From an academic perspective, considerable progress has been made toward the development of transition metal catalysts able to promote this hydration process under mild conditions. In this context, with regard to activity, selectivity, functional group compatibility and modes of reactivity, the most versatile nitrile hydration catalysts discovered to date are based on ruthenium complexes. Herein, a comprehensive account of the different homogeneous ruthenium catalysts described in the literature is presented. Heterogeneous ruthenium-based systems are also discussed.
\end{abstract}

Keywords: Ruthenium; Hydration reactions; Nitriles; Amides; Homogeneous catalysis

\title{
1. Introduction
}

The amide functionality is one of the most relevant in organic and biological chemistry. Amides are present in multitude of natural products, pharmaceuticals and drug candidates, and have found applications as starting materials in the preparation of various industrial products including detergents, lubricants and polymers [1]. Amides are commonly prepared by the reaction of activated carboxylic acid derivatives (acid chlorides, anhydrides and esters) with amines including ammonia [2], or by direct union of the acids with the amines assisted by coupling reagents, such as carbodiimides or $1 H$-benzotriazole derivatives [3]. However, despite being of great applicability, these methods suffer from a low atom economy and are associated to the generation of large quantities of waste products, making their environmental profile unfavourable. For this reasons, increasing attention is being devoted to the development of more efficient and sustainable synthetic routes that allow access to this important class of compounds [4].

The hydration of nitriles is probably the simplest method for preparing primary amides in an atom-economical manner (Scheme 1). However, conventional protocols for hydrating nitriles involve the use of highly acidic/basic media and harsh reaction conditions, methods that are frequently unable to control hydrolysis to the corresponding carboxylic acids (Scheme 1) and are not compatible with many sensitive functional groups [2]. The formation 
of a large amount of salts after neutralization is another problem associated with these classical methodologies.

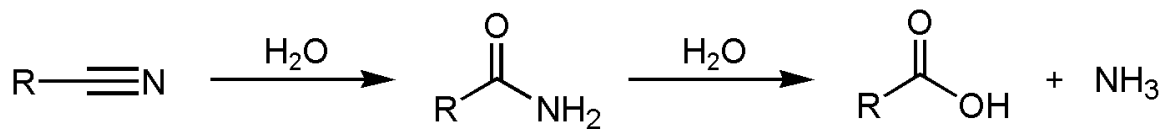

Scheme 1. The nitrile hydration and amide hydrolysis reactions.

To overcome these drawbacks, considerable efforts have been expended in the search of alternative methods for the nitrile hydration process. In this context, nitrile hydratases (NHases), a family of enzymes containing non-heme low spin Fe(III) or non-corrinoid lowspin $\mathrm{Co}(\mathrm{III})$ active centers, have demonstrated great potential to promote the selective transformation of nitriles into amides under mild conditions [5]. In fact, this type of biocatalysts have found application in the commercial production of some relevant amides, such as acrylamide, nicotinamide, 5-cyanovaleramide and levetiracetam, an antiepileptic drug marketed under the trade name Keppra ${ }^{\circledR}$ (Scheme 2) [5,6]. However, the necessity of special procedures to handle microorganisms, their high cost and narrow substrate specificity restrict severely the use of NHases.

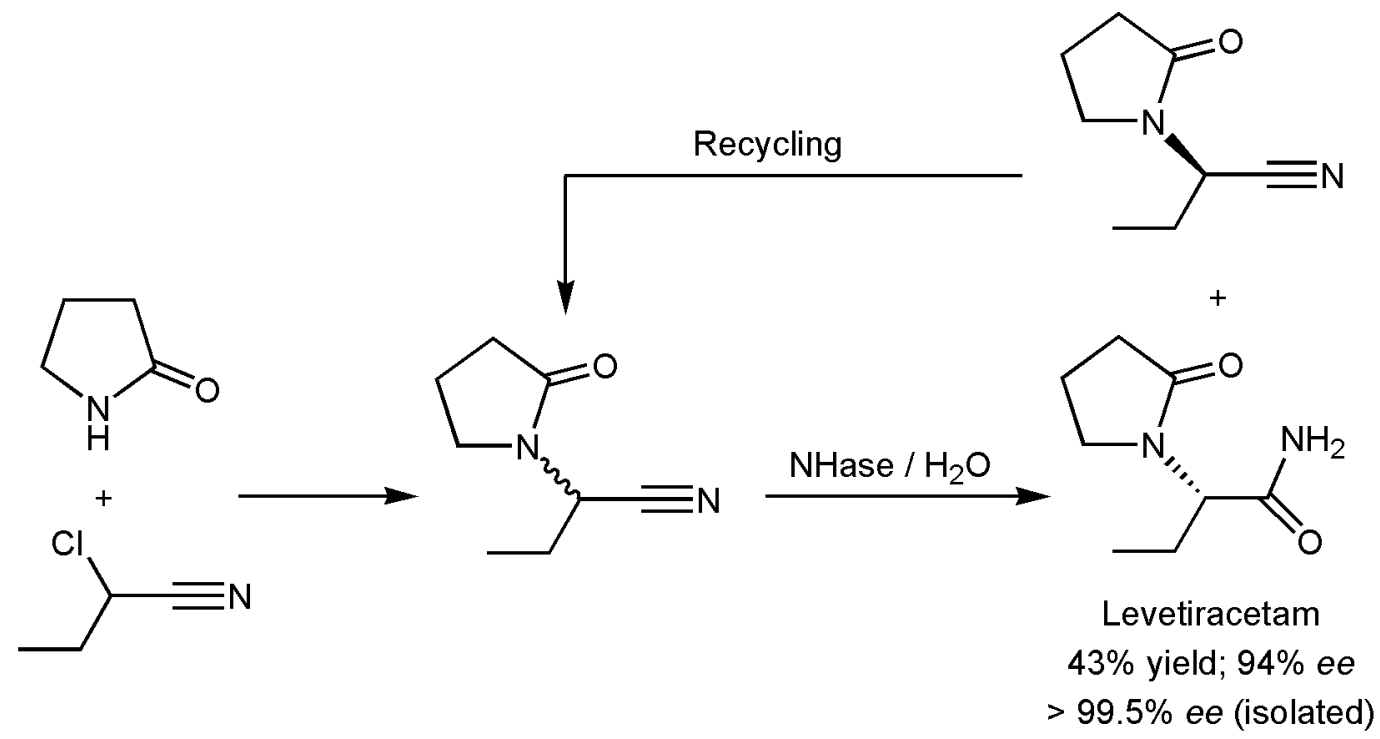

Scheme 2. Synthetic route of levetiracetam employing a nitrile hydratase.

Metal ions are able to favour nitrile hydration by activating the nitrile substrate, the water nucleophile, or both upon coordination. Accordingly, a variety of homogeneous [7] and heterogeneous [8] metal-based catalysts, showing a high selectivity to the amide under milder conditions to those employed with strong acids or bases, have been described in the 
literature during the last two decades. For synthetic purposes, given their greater substrate scope and easier handling, these methods based on metal catalysts are much appealing than the enzymatic ones. This fact is endorsed, for example, by the extraordinary success achieved by the hydrido-platinum(II) complex $\left[\mathrm{PtH}\left\{\left(\mathrm{PMe}_{2} \mathrm{O}\right)_{2} \mathrm{H}\right\}\left(\mathrm{PMe}_{2} \mathrm{OH}\right)\right]$ developed by Parkins and co-workers (Fig. 1) [9]. This Pt system is able to catalyze the selective hydration of a wide range of nitriles, including very bulky nitriles, unsaturated nitriles (such as acrylonitrile) and nitriles containing acid and base-sensitive functional groups, under relatively mild $\left(70-100{ }^{\circ} \mathrm{C}\right)$ and neutral reaction conditions. All these properties, along with its exquisite functional group tolerance, has allowed the implementation of $\left[\mathrm{PtH}\left\{\left(\mathrm{PMe}_{2} \mathrm{O}\right)_{2} \mathrm{H}\right\}\left(\mathrm{PMe}_{2} \mathrm{OH}\right)\right]$ in the synthesis of a large number of complex organic molecules and natural products [10].

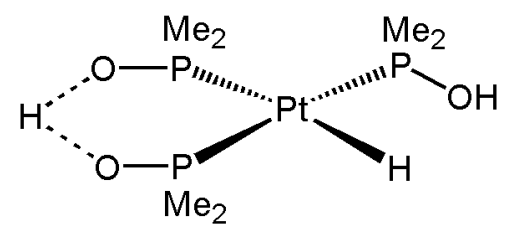

Fig. 1. Structure of the Parkins catalyst.

Ruthenium compounds constitute a versatile class of catalysts for synthetic organic chemistry and feature a large panel of applications [11]. There are several aspects that make ruthenium interesting for homogeneous catalysis, such as its rich coordination chemistry, the wide range of oxidation states that it can adopt (from -2 to +8 ) or its ability to accommodate a large variety of ligands in various coordination geometries. No less important is the fact that ruthenium is much less expensive than other platinum-group metals such as palladium, platinum, rhodium and iridium. Ruthenium complexes have therefore a great potential for the development of new nitrile hydration catalysts. Indeed, the most recent breakthroughs in the field have been reached using this metal. Herein, a comprehensive account of the different ruthenium-based catalysts for nitrile hydration described in the literature is presented. Both homogeneous and heterogeneous systems will be discussed.

\section{Homogeneous ruthenium-based catalysts}

The application of a ruthenium complex to promote the selective hydration of nitriles to primary amides was described for the first time by Taube and co-workers in the 1970's [12]. Thus, using a stoichiometric amount of $\left[\mathrm{RuCl}\left(\mathrm{NH}_{3}\right)_{5}\right][\mathrm{Cl}]_{2}$ in combination with $\mathrm{Ag}_{2} \mathrm{O}$, 
trifluoroacetic acid and zinc amalgam, they were able to transform in high yields (64-95\%) several aromatic, aliphatic and $\alpha, \beta$-unsaturated organonitriles into the corresponding amides after $6-8 \mathrm{~h}$ of heating at $40-50{ }^{\circ} \mathrm{C}$ in wet dichloromethane. However, despite this early discovery, it was not until 1992 that the first truly catalytic system could be developed by Murahashi and co-workers employing the ruthenium-dihydride complex $\left[\mathrm{RuH}_{2}\left(\mathrm{PPh}_{3}\right)_{4}\right]$ as catalyst $[13,14]$. In the presence of $3 \mathrm{~mol} \%$ of this complex and 2 molar equivalents of water, several organonitriles were successfully hydrated in 1,2-dimethoxyethane (DME) under neutral conditions, giving the desired amides in excellent yields (77-94\%) after 24 hours of heating at $120{ }^{\circ} \mathrm{C}\left(\mathrm{TOF} \leq 2 \mathrm{~h}^{-1}\right.$; Scheme 3) [13]. A reaction pathway involving the intermolecular nucleophilic addition of water to the coordinated nitrile, to give an iminolate complex, was proposed. Reductive elimination, isomerization of the iminol to the amide, and subsequent dissociation regenerates the catalytically active ruthenium species [13c].

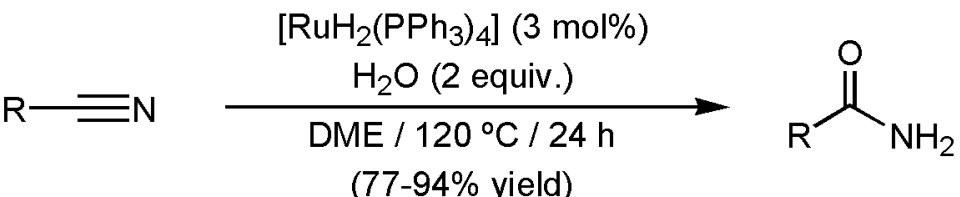

$\mathrm{R}=\mathrm{Me}, \mathrm{Ph}, \mathrm{Bn}, n-\mathrm{C}_{5} \mathrm{H}_{11}, \mathrm{CH}_{2} \mathrm{CH}_{2} \mathrm{R}^{\prime}\left(\mathrm{R}^{\prime}=\mathrm{CO}_{2} \mathrm{Me}, 1\right.$-pyrrolidinyl-2-one $)$

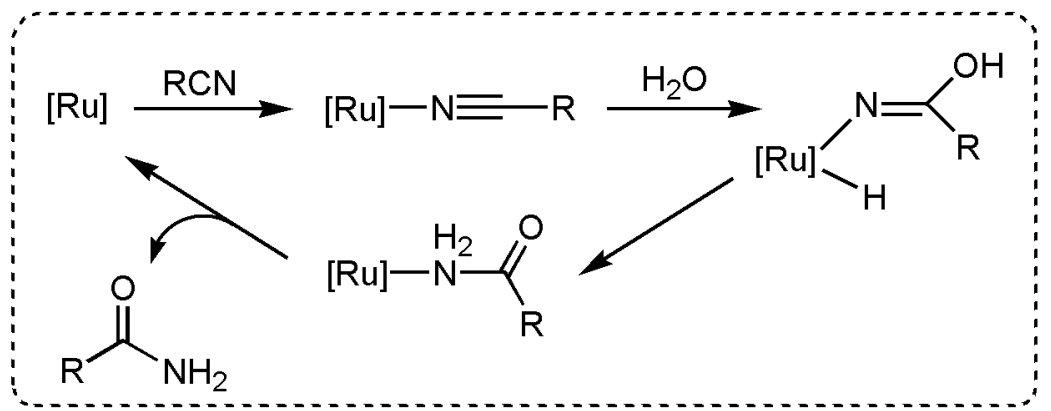

Scheme 3. Catalytic hydration of nitriles by means of complex $\left[\mathrm{RuH}_{2}\left(\mathrm{PPh}_{3}\right)_{4}\right]$.

Under the same reaction conditions, complex $\left[\mathrm{RuH}_{2}\left(\mathrm{PPh}_{3}\right)_{4}\right]$ was also able to transform a large variety of $\delta$-ketonitriles into ene-lactams through a tandem process involving the initial hydration of the $\mathrm{C} \equiv \mathrm{N}$ unit, followed by intramolecular condensation of the resulting keto-amide (representative examples are shown in Scheme 4) [13]. 
<smiles>CCOC(=O)C1(CCC#N)CCCCC1=O</smiles>

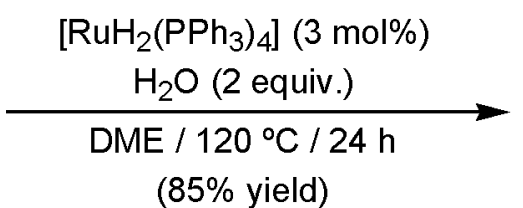<smiles>CCOC(=O)C12CCCC=C1NC(=O)CC2</smiles><smiles>CC1CC(=O)C(CCC#N)C(=O)C1</smiles><smiles>CC1CC(=O)C2=C(C1)NC(=O)CC2</smiles>

Scheme 4. Catalytic synthesis of ene-lactams using complex $\left[\mathrm{RuH}_{2}\left(\mathrm{PPh}_{3}\right)_{4}\right]$.

The usefulness of this tandem reaction was fully demonstrated by the total synthesis of the naturally occurring alkaloid (-)-pumiliotoxin C (3) starting from the $\delta$-ketonitrile $\mathbf{1}$, where the $\left[\mathrm{RuH}_{2}\left(\mathrm{PPh}_{3}\right)_{4}\right]$-catalyzed conversion of $\mathbf{1}$ to ene-lactam 2 was one of the key steps (Scheme 5) [13]. Deisopropylidenation of 1 (retroaldol reaction), nitrile hydration and cyclization occurred sequentially at $160{ }^{\circ} \mathrm{C}$ to give 2 in a one-pot manner.<smiles>CC(C)=C1CC[C@@H](C)C(CCC#N)C1=O</smiles>

1



$(56 \%$ yield $)$<smiles>CC(=O)[CH2+]CC1=C(NC(C)=O)CCC[C@H]1C</smiles><smiles>CCC[C@H]1CC[C@H]2[C@@H](C)CCC[C@H]2N1</smiles>

3

$(-)$-pumiliotoxin C

Scheme 5. The role of complex $\left[\mathrm{RuH}_{2}\left(\mathrm{PPh}_{3}\right)_{4}\right]$ in the total synthesis of the alkaloid (-)-pumiliotoxin C.

The half-sandwich hydrido-ruthenium(II) complex $\left[\mathrm{RuH}\left(\eta^{5}-\mathrm{C}_{9} \mathrm{H}_{7}\right)(\mathrm{dppm})\right](\mathbf{4} ; \mathrm{dppm}=$ bis(diphenylphosphino)methane; $\mathrm{C}_{9} \mathrm{H}_{7}=$ indenyl) revealed also as a quite effective catalyst for the selective conversion of nitriles to amides [15]. Thus, performing the reactions directly in water at $120{ }^{\circ} \mathrm{C}$ with $0.1 \mathrm{~mol} \%$ of 4 , TOF and TON values of up to $12 \mathrm{~h}^{-1}$ and 865 , respectively, could be reached in the hydration of acetonitrile and benzonitrile. Worthy of note, its chloride counterpart $\left[\operatorname{RuCl}\left(\eta^{5}-\mathrm{C}_{9} \mathrm{H}_{7}\right)(\mathrm{dppm})\right]$ was found to be completely 
ineffective, suggesting that the hydride ligand plays a key role during the catalytic events. To clarify this point, Density Functional Theory (DFT) calculations were performed, pointing out an unusual promoting effect of the hydride. Thus, as shown in Scheme 6, this ligand activates the incoming water molecule through a $\mathrm{Ru}-\mathrm{H} \cdots \mathrm{H}-\mathrm{OH}$ dihydrogen-bonding interaction, favoring the nucleophilic attack of water on the coordinated nitrile. In this ratedetermining step an iminol intermediate is produced, which quickly tautomerizes to the amide upon dissociation. Remarkably, despite the known tendency of the indenyl ligand to undergo $\eta^{5} \rightarrow \eta^{3}$ ring slippage [16], the DFT calculations indicated that coordination of the nitrile to ruthenium takes place by dissociation of one arm of the diphosphine dppm.

<smiles></smiles>

4

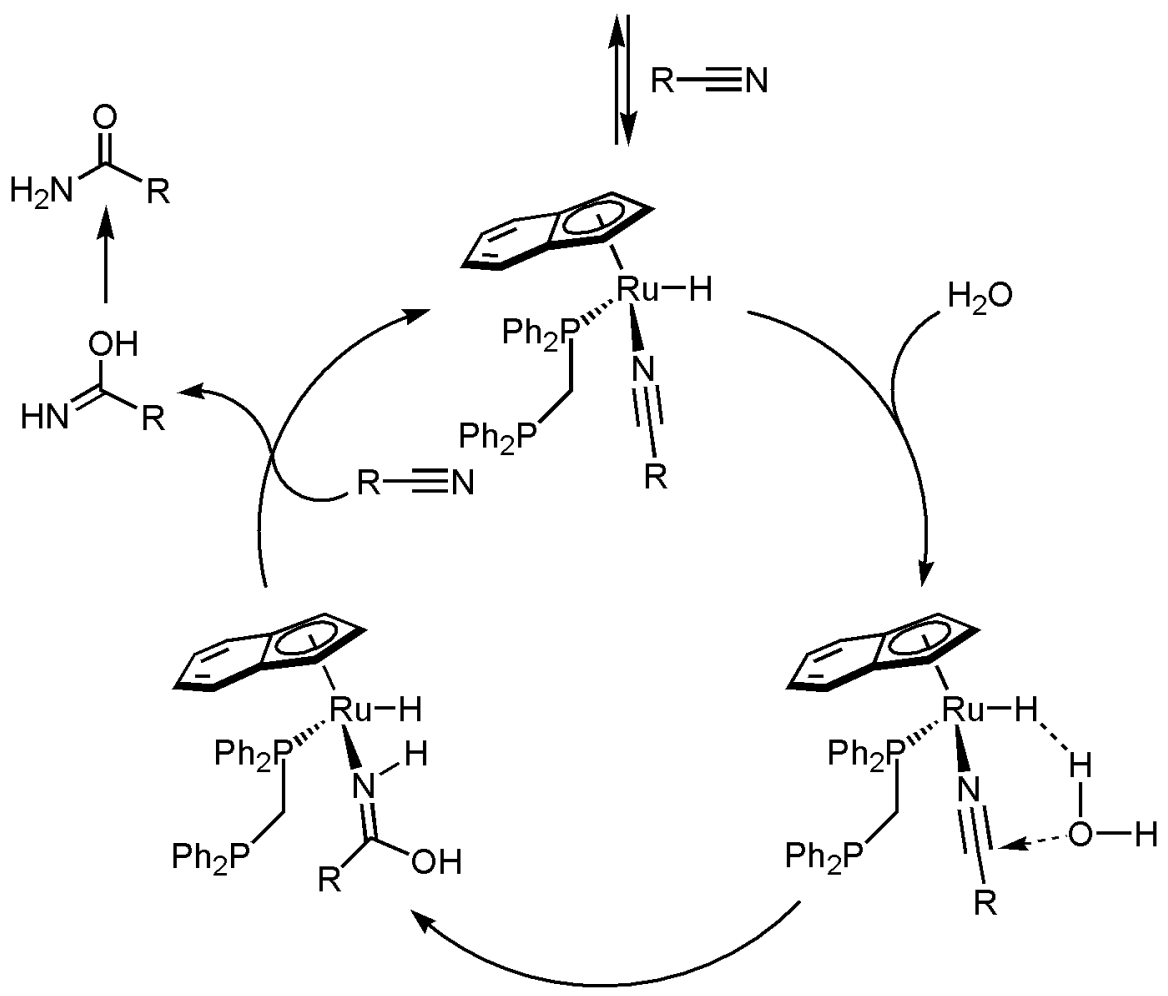

Scheme 6. Promoting effect of the hydride ligand of complex 4 during the catalytic hydration of nitriles.

The same promoting effect of the hydride ligand, via $\mathrm{Ru}-\mathrm{H} \cdots \mathrm{H}-\mathrm{OH}$ dihydrogenbonding, was evidenced by means of DFT calculations in the reaction of the isoelectronic hydro(trispyrazolyl)borate complex $\left[\mathrm{RuH}(\mathrm{Tp})\left(\mathrm{PPh}_{3}\right)(\mathrm{NCMe})\right](5)$ with water, which led to the formation the acetamido derivative $\left[\mathrm{Ru}(\mathrm{Tp})\left(\mathrm{PPh}_{3}\right)\left(\mathrm{H}_{2} \mathrm{O}\right)\{\mathrm{NHC}(=\mathrm{O}) \mathrm{Me}\}\right](6)($ Scheme 7$)$ 
[17]. As in the preceding case, a marked difference in reactivity with respect to the corresponding chloride complex $\left[\mathrm{RuCl}(\mathrm{Tp})\left(\mathrm{PPh}_{3}\right)(\mathrm{NCMe})\right]$ was observed, since the latter resulted to be inert towards water.
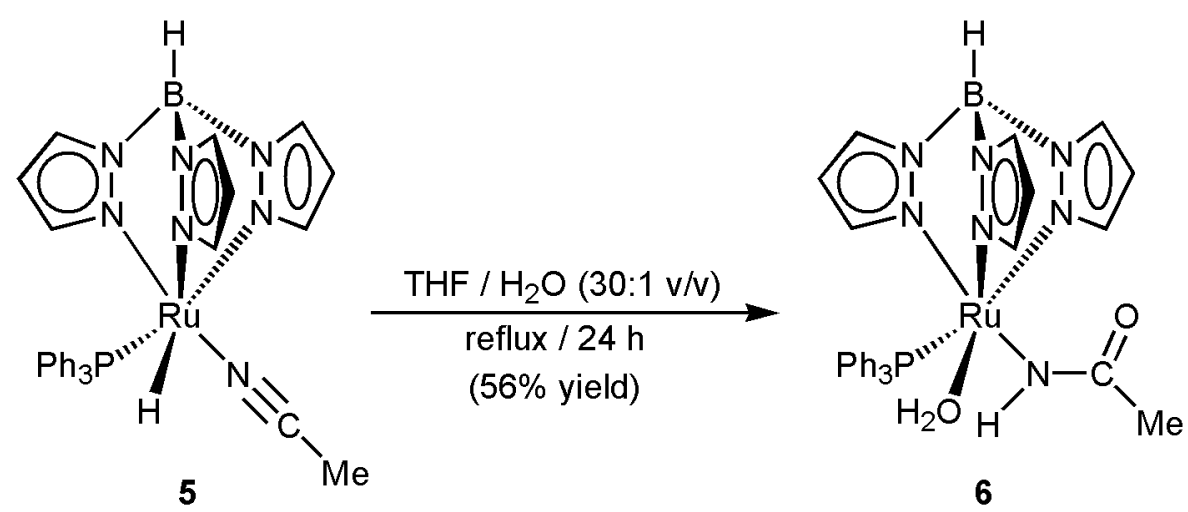

Scheme 7. Reactivity of the hydrido-Ru(II) complex $\left[\mathrm{RuH}(\mathrm{Tp})\left(\mathrm{PPh}_{3}\right)(\mathrm{NCMe})\right](5)$ towards water.

The hydrido and acetamido complexes 5 and $\mathbf{6}$ were able to promote the selective conversion of several organonitriles to the corresponding primary amides, in 1,4dioxane/water mixtures, at $120-150{ }^{\circ} \mathrm{C}$ [18]. However, modest results in terms of activity were in general obtained, with maximum TOF and TON values of $8 \mathrm{~h}^{-1}$ and 200, respectively, being reached in the hydration of 4-chlorobenzonitrile by the acetamido complex $6(0.5 \mathrm{~mol} \%)$ at $150{ }^{\circ} \mathrm{C}$. Probably, the most relevant aspect of $\left[\mathrm{Ru}(\mathrm{Tp})\left(\mathrm{PPh}_{3}\right)\left(\mathrm{H}_{2} \mathrm{O}\right)\{\mathrm{NHC}(=\mathrm{O}) \mathrm{Me}\}\right](\mathbf{6})$ is related to its mechanism of action, which was revealed through NMR measurements in combination with DFT calculations (Scheme 8). The mechanism involves the initial displacement of the $\mathrm{H}_{2} \mathrm{O}$ ligand by a nitrile molecule, followed by the isomerization of the $\mathrm{N}$-bonded acetamido ligand to an $O$-bonded iminolate. Then, intramolecular nucleophilic attack of the nitrogen atom of the iminolate unit to the coordinated nitrile occurs to generate the intermediate species 7, featuring a chelating $N$ imidoylimidato ligand. Final nucleophilic attack of water to this intermediate breaks the C-N bond of the metallacycle and generates an iminol-iminolate species from which the amide product is generated. The intermediate $N$-imidoylimidato complex 7 could be independently prepared, its structure fully confirmed by X-ray crystallography, and its involvement in the catalytic transformation experimentally demonstrated [19]. The DFT calculations also indicated that the highest energy barrier in the catalytic cycle is associated to the ringopening of this remarkably stable intermediate by water. 


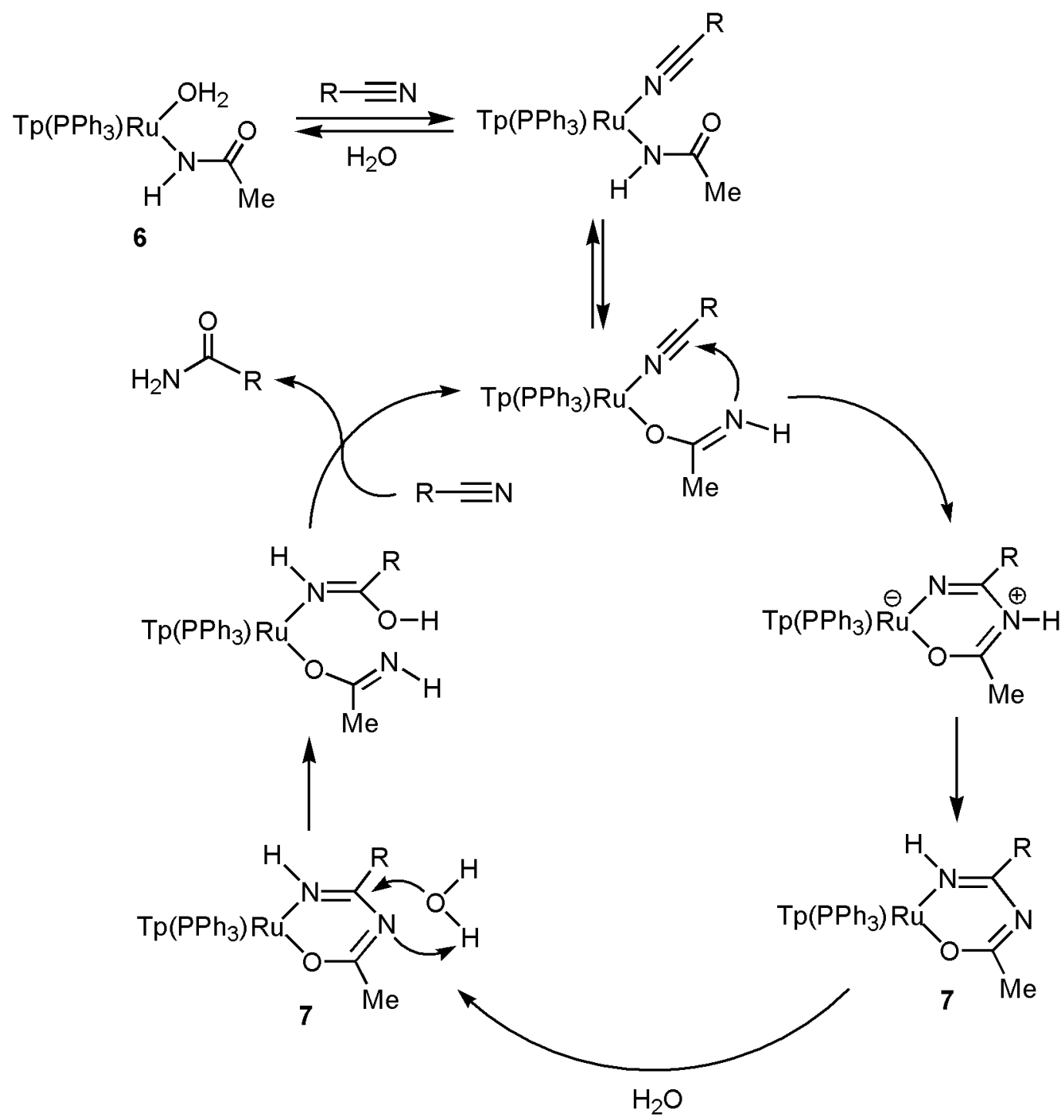

Scheme 8. Catalytic cycle for the hydration of nitriles promoted by the acetamido complex $\left[\mathrm{Ru}(\mathrm{Tp})\left(\mathrm{PPh}_{3}\right)\left(\mathrm{H}_{2} \mathrm{O}\right)\{\mathrm{NHC}(=\mathrm{O}) \mathrm{Me}\}\right](\mathbf{6})$.

The tetranuclear cluster $\mathbf{8}$ and the mononuclear derivative $\mathbf{9}$ are additional examples of hydrido-ruthenium complexes able to promote the selective hydration of $\mathrm{C} \equiv \mathrm{N}$ bonds (Fig. 2). In particular, the former $(1 \mathrm{~mol} \%)$ proved to be effective in the hydration of a large variety of aromatic, heteroaromatic, $\alpha, \beta$-unsaturated and aliphatic nitriles, employing ${ }^{\mathrm{i}} \mathrm{PrOH}$, THF or DME as solvent, 10-20 equivalents of water and temperature regimes in the range $80-100{ }^{\circ} \mathrm{C}$ [20]. The desired amides were produced in all the cases in excellent yields (84-99\%) after 6$18 \mathrm{~h}$ of heating (TOF and TON values up to $16 \mathrm{~h}^{-1}$ and 99). On the basis of kinetic analyses and NMR studies, formation of a mononuclear hydrido-ruthenium species was proposed during the hydration of electron-rich nitriles, while the tetrameric ruthenium core remained intact with electron-poor substrates. There was no noticeable decrease in the rate of the hydration when $\operatorname{Hg}(0)$ was added to the reaction mixtures, which suggested to the authors 
that, despite decomposition of the cluster occurs with electron-rich nitriles, the catalytically active species remains homogeneous. Concerning the mononuclear complex 9, it was exclusively applied to the transformation of benzonitrile into benzamide [21]. Compared to cluster $\mathbf{8}$, the activity of $\mathbf{9}$ was remarkably lower (TOF $<1 \mathrm{~h}^{-1}$ ) under similar reaction conditions (acetone, $80^{\circ} \mathrm{C}, 0.5 \mathrm{~mol} \%$ of $\mathrm{Ru}, 10$ equiv. of $\mathrm{H}_{2} \mathrm{O}$ ). In addition, it deactivated over time so that the complete conversion of the substrate could not be achieved even after $40 \mathrm{~h}$ of heating.

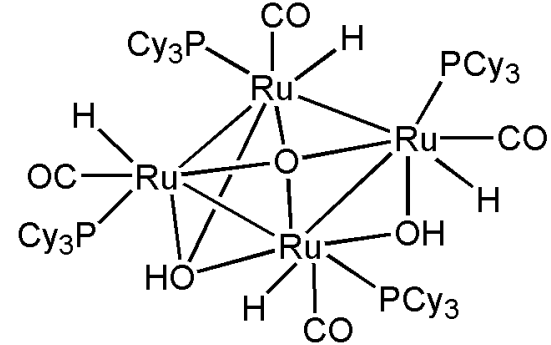

8

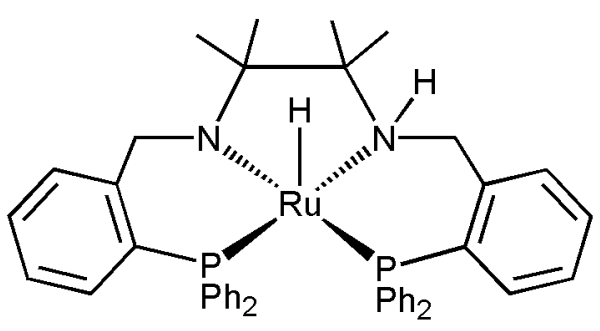

9

Fig. 2. Structure of the hydrido-ruthenium complexes $\mathbf{8}$ and $\mathbf{9 .}$

The key role played by the auxiliary ligands in this catalytic transformation was clearly evidenced by Oshiki and co-workers using the octahedral ruthenium(II) derivative cis$\left[\mathrm{Ru}(\mathrm{acac})_{2}\left(\mathrm{PPh}_{2} \mathrm{py}\right)_{2}\right]\left(\mathbf{1 0} ;\right.$ acac $=$ acetylacetonate; $\mathrm{PPh}_{2} \mathrm{py}=2$-(diphenylphosphino $)$ pyridine $)$ [22]. Unlike its analog with triphenylphosphine, i.e. cis-[Ru(acac $\left.)_{2}\left(\mathrm{PPh}_{3}\right)_{2}\right](\mathbf{1 1})$, complex 10 was able to hydrate efficiently a large number of nitriles at $180{ }^{\circ} \mathrm{C}$, employing DME as solvent and 4 equivalents of water. Impressive TOF values of up to $20900 \mathrm{~h}^{-1}$ could be reached with this ruthenium catalyst. As an illustrative example of the remarkably different catalytic behavior shown by complexes $\mathbf{1 0}$ and 11, the results obtained in the hydration of benzonitrile with a metal loading of $2 \mathrm{~mol} \%$ are presented in Scheme 9.
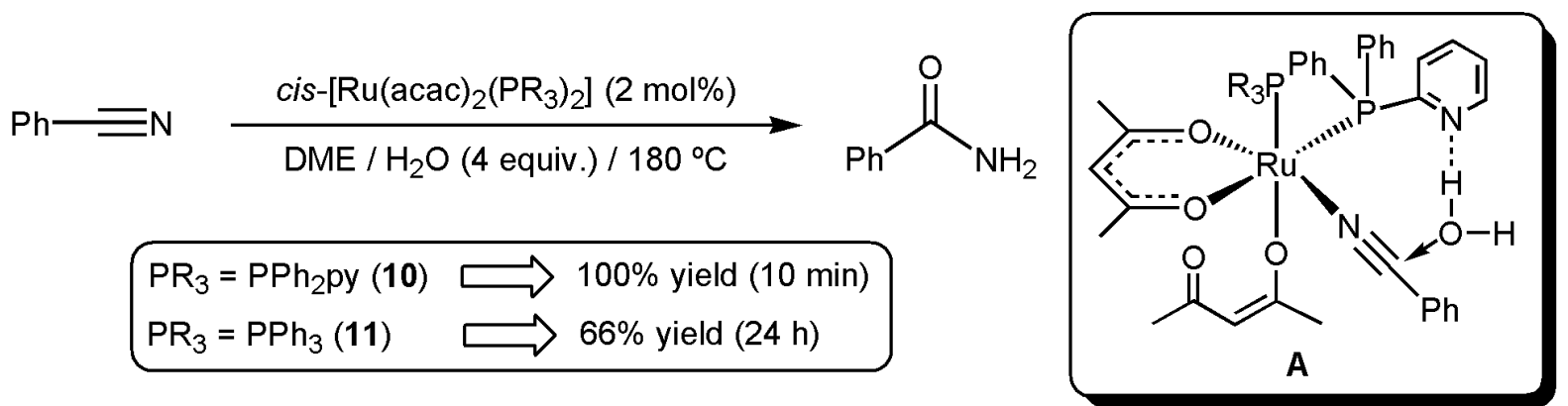

Scheme 9. Cooperative effect of the 2-(diphenylphosphino)pyridine ligand in benzonitrile hydration. 
Thus, despite both catalysts have the same structure and similar electronic and steric properties, complex cis-[Ru(acac $\left.)_{2}\left(\mathrm{PPh}_{2} \mathrm{py}\right)_{2}\right]$ (10) is much more active than cis$\left[\mathrm{Ru}(\mathrm{acac})_{2}\left(\mathrm{PPh}_{3}\right)_{2}\right](\mathbf{1 1})$ due to the ability of the 2-(diphenylphosphino)pyridine ligand to establish an hydrogen bond with water. In this way, the formation of intermediate $\mathbf{A}$, not accessible when $\mathrm{PPh}_{3}$ is used as ligand, activates the water molecule facilitating its addition to the coordinated nitrile. Such a cooperative effect of the $\mathrm{PPh}_{2} \mathrm{py}$ ligand is a clear example of the so-called "bifunctional catalysis", in which the substrates are activated by the combined action of the metal, which acts as a Lewis acid, and the ligand, which acts as a Lewis base. Such a concept has been largely exploited in homogeneous catalysis during the last years [23]. Similarly to cis-[Ru(acac $\left.)_{2}\left(\mathrm{PPh}_{3}\right)_{2}\right](\mathbf{1 1})$, mediocre results were also obtained with complexes cis-[Ru(acac $\left.)_{2}\left(\mathrm{PMe}_{3}\right)_{2}\right]$ and cis-[Ru(acac $\left.)_{2}\left(\mathrm{PBu}_{3}\right)_{2}\right]$ containing noncooperative phosphine ligands [22d]. On the other hand, we must also point out that cis$\left[\mathrm{Ru}(\mathrm{acac})_{2}\left(\mathrm{PPh}_{2} \mathrm{py}\right)_{2}\right](\mathbf{1 0})$ only displayed an exceptional reactivity at $180{ }^{\circ} \mathrm{C}$ (Scheme 9). A decreasing of the temperature to $150{ }^{\circ} \mathrm{C}$ decreased the TOF to $222 \mathrm{~h}^{-1}$. At $80{ }^{\circ} \mathrm{C}$, the activity of $\mathbf{1 0}$ was completely halted [22b].

Employing the bis(allyl)-ruthenium(II) complex $\left[\mathrm{Ru}\left(\eta^{3}-2-\mathrm{C}_{3} \mathrm{H}_{4} \mathrm{Me}\right)_{2}(\operatorname{cod})\right](\operatorname{cod}=1,5-$ cyclooctadiene; 0.5-1 mol\%), in combination with different pyridyl-phosphines (see Fig. 3; 2-3 equiv. per $\mathrm{Ru}$ ), Oshiki and co-workers were able to perform the selective hydration of a variety of organonitriles in DME at $80^{\circ} \mathrm{C}$ [24]. However, the TOF values reached were only modest (up to $5 \mathrm{~h}^{-1}$ ) and incomplete conversions were in some cases observed. The best activities were obtained with the 2-diphenylphosphino-4-pyridyl(dimethyl)amine ligand, fact that, according to the authors, is related to the increased ability of the nitrogen atom of the pyridyl ring to act as a $\mathrm{H}$-bond acceptor due to the presence of the electron-donating dimethylamino substituent in the structure.
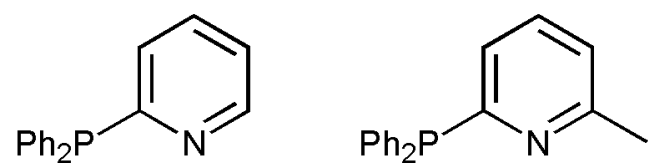<smiles>CN(C)c1ccnc(Pc2ccccc2)c1</smiles>

Fig. 3. Pyridyl-phosphines employed by Oshiki and co-workers in the $\left[\mathrm{Ru}\left(\eta^{3}-2-\mathrm{C}_{3} \mathrm{H}_{4} \mathrm{Me}\right)_{2}(\mathrm{cod})\right]$-catalyzed nitrile hydration reactions.

Inspired by the works of Oshiki and co-workers, Šmejkal and Breit described the preparation and catalytic behaviour of the bis(acetylacetonate)-ruthenium(II) complexes 1214, bearing the potentially cooperative $P$-donor ligands 6-diphenylphosphino- $N$-pivaloyl-2- 
aminopyridine and 3-diphenylphosphinoisoquinolone (Fig. 4) [25]. All of them were able to promote the selective conversion of the model substrate 4-methylbenzonitrile into 4methylbenzamide. However, under the same reaction conditions (in DME at $150{ }^{\circ} \mathrm{C}$ ), their effectiveness was comparatively lower (TOF values up to $20 \mathrm{~h}^{-1}$ ) to that shown by complex cis-[Ru(acac $\left.)_{2}\left(\mathrm{PPh}_{2} \mathrm{py}\right)_{2}\right](\mathbf{1 0})$. Within this family of compounds the observed catalytic activity order $12>13>14$ was explained by the weaker donor character of the 3diphenylphosphinoisoquinolone ligand compared to the 6-diphenylphosphino- $N$-pivaloyl-2aminopyridine one, which makes the ruthenium atom a stronger Lewis acid center. Also, as pointed out for the authors, an additional reason for the low catalytic activity shown by $\mathbf{1 4}$ might be related with the chelation of the pyridyl-phosphine ligand to ruthenium. This fact, evidenced during the preparation of this complex, would inhibit the formation of the required coordinative unsaturated ruthenium species that are needed for the activation of the nitrile.

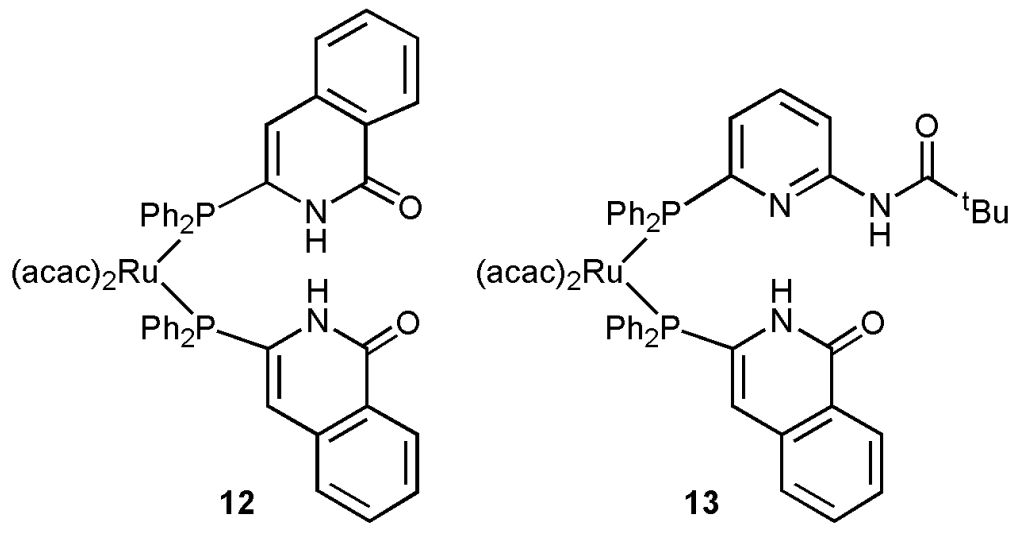<smiles>CC(C)(C)C(=O)Nc1cccc(P([R](c2ccccc2)P(c2ccccc2)c2ccccc2)c2ccccc2)n1</smiles>

Fig. 4. Structure of the bis(acetylacetonate)-ruthenium(II) complexes 12-14.

As evidenced by NMR spectroscopy and catalytic experiments performed with the isolated chelate complexes, $\kappa^{2}-(P, N)$-coordination of the pyridyl-phosphines 2(diphenylphosphino)pyridine and 2-diphenylphosphino-4-pyridyl(dimethyl)amine (Fig. 3) was behind the poor activities (TOF $<1 \mathrm{~h}^{-1}$ ) found by Crochet, Cadierno and co-workers for a series of arene-ruthenium(II) and bis(allyl)-ruthenium(IV) complexes containing these ligands [26]. In order to avoid the chelation of the pyridyl unit, related ruthenium complexes 15 and 16 bearing the pyridyl-phosphine $\mathrm{PPh}_{2}$ (py-6-tert-amyl) were also synthesized by the same authors as potentially more active catalysts (Scheme 10) [26]. As expected, the presence of the bulky tert-amyl substituent adjacent to nitrogen totally suppressed the coordination ability of the pyridyl unit. However, despite this fact, the catalytic activities found in the hydration of the model benzonitrile substrate at $100{ }^{\circ} \mathrm{C}$ were very modest (TOF 
$\left.<1 \mathrm{~h}^{-1}\right)$, and comparable to those shown by complexes $\left[\mathrm{RuCl}_{2}\left(\eta^{6}\right.\right.$-arene $\left.)\left(\mathrm{PPh}_{3}\right)\right]($ arene $=$ benzene, $p$-cymene $)$ and $\left[\mathrm{RuCl}_{2}\left(\eta^{3}: \eta^{3}-\mathrm{C}_{10} \mathrm{H}_{16}\right)\left(\mathrm{PPh}_{3}\right)\right]\left(\mathrm{C}_{10} \mathrm{H}_{16}=2\right.$,7-dimethylocta-2,6-diene1,8-diyl) containing the non-cooperative triphenylphosphine ligand. Steric congestion around the Lewis acid metal center, preventing the approach and coordination of the benzonitrile molecule, was evoked to explain low effectiveness shown by complexes 15 and 16 [27].

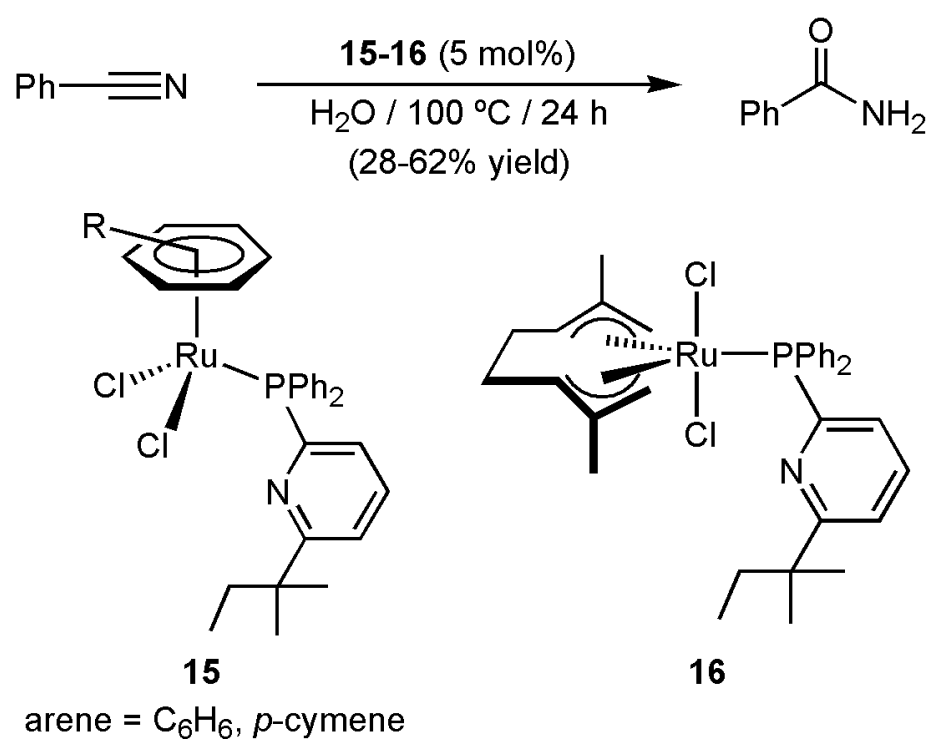

Scheme 10. Catalytic hydration of benzonitrile using the pyridyl-phosphine ruthenium complexes $\mathbf{1 5}$ and 16.

In the search for cooperative effects of the ligands, the catalytic behaviour of different arene-ruthenium(II) complexes 17-19 with potentially H-bond accepting amino-arylphosphines was also explored by Crochet, Cadierno and co-workers (Fig. 5) [28]. All these complexes $(5 \mathrm{~mol} \%)$ were able to hydrate the model benzonitrile substrate in pure water as solvent, leading to the selective formation of benzamide in $43-98 \%$ yield after $24 \mathrm{~h}$ of heating at $100{ }^{\circ} \mathrm{C}$. Using the most active complex $\left[\mathrm{RuCl}_{2}\left\{\kappa^{1}(P)-3-\mathrm{Ph}_{2} \mathrm{PC}_{6} \mathrm{H}_{4} \mathrm{CH}_{2} \mathrm{NH}^{\mathrm{t}} \mathrm{Bu}\right\}\left(\eta^{6}-\right.\right.$ $\left.\left.1,3,5-\mathrm{C}_{6} \mathrm{H}_{3} \mathrm{Me}_{3}\right)\right]$, the generality of the reaction could be demonstrated for a number of functionalized benzonitriles, as well as nitriles containing alkyl- and alkenyl-CN bonds. Remarkably, although the activity of complexes 17-19 was only moderate (TOF up to $3 \mathrm{~h}^{-1}$ ), they were comparatively more active than their corresponding non-functionalizalized triphenylphosphine counterparts $\left[\mathrm{RuCl}_{2}\left(\eta^{6}\right.\right.$-arene $\left.)\left(\mathrm{PPh}_{3}\right)\right]$ ( TOF $<0.1 \mathrm{~h}^{-1}$ under identical reaction conditions). This fact was explained by the participation of the pendant amino group of the ligands as an internal Brønsted base during catalysis, generating the more nucleophilic $\mathrm{OH}^{-}$group (Fig. 5). In accord with this proposal, rate enhancements were observed when the catalytic hydration of benzonitrile by complexes $\left[\mathrm{RuCl}_{2}\left(\eta^{6}\right.\right.$-arene $\left.)\left(\mathrm{PPh}_{3}\right)\right]$ was performed in 
the presence of free $\mathrm{PhCH}_{2} \mathrm{NH}^{\mathrm{i}} \mathrm{Pr}$ or $\mathrm{PhCH}_{2} \mathrm{NH}^{\mathrm{t}} \mathrm{Bu}$, amines that mimic the substituents of the phosphine ligands in complexes 17-19 [28].

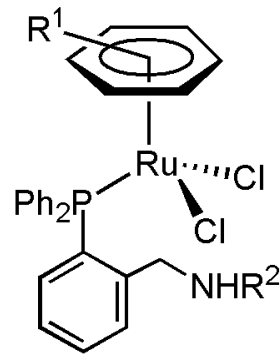

17

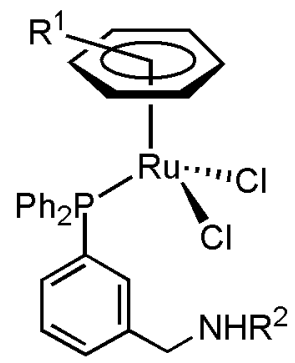

18

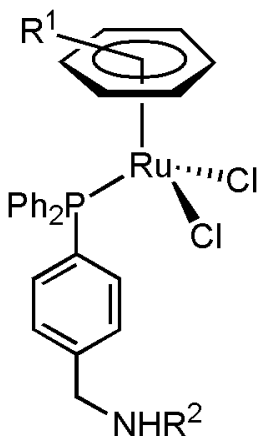

19 arene $=\mathrm{C}_{6} \mathrm{H}_{6}, p$-cymene, $1,3,5-\mathrm{C}_{6} \mathrm{H}_{3} \mathrm{Me}_{3}, \mathrm{C}_{6} \mathrm{Me}_{6} ; \mathrm{R}^{2}={ }^{\mathrm{i}} \mathrm{Pr},{ }^{\mathrm{t}} \mathrm{Bu}$

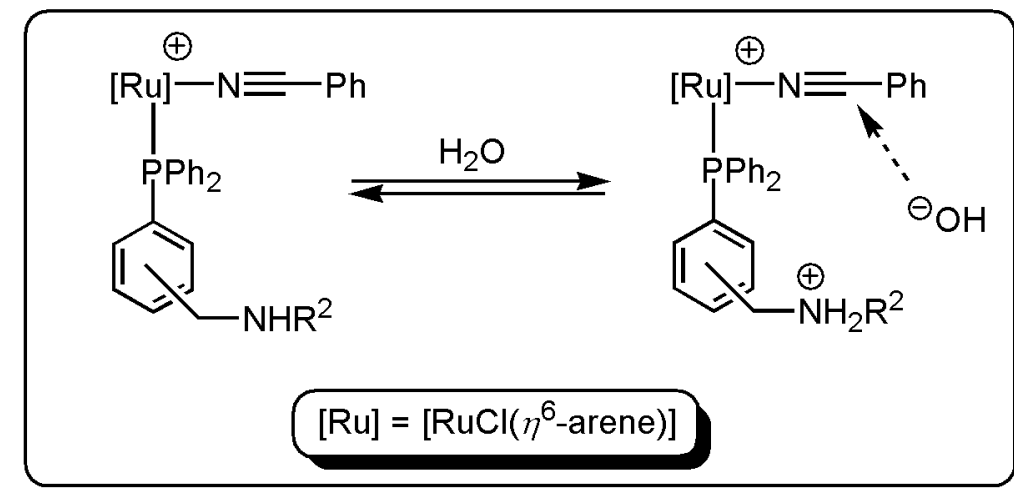

Fig. 5. Structure of the arene-ruthenium(II) complexes 17-19 and its mechanism of action.

In order to facilitate the solubility of the catalysts in water, remarkable efforts have been devoted in recent years to the study of ruthenium complexes bearing water-soluble phosphines. In this context, a possible cooperative effect of the "cage-like" phosphines PTA, PTA-Bn, DAPTA, THPA and THDP [29], via H-bonding of the nucleophilic water molecule with the nitrogen atoms present in their structures, has been proposed to explain the remarkably higher effectiveness shown by the arene-ruthenium(II) 20 [30] and bis(allyl)ruthenium(IV) complexes 21-22 [31] in comparison with the related species 23-24 bearing the sulphonated phosphine TPPMS, in which such an interaction cannot be established (Fig. 6). The arene-ruthenium(II) catalysts $\mathbf{2 0}$ also showed a much higher reactivity in water than complexes $\left[\mathrm{RuCl}_{2}\left(\eta^{6}\right.\right.$-arene $\left.)\left(\mathrm{PR}_{3}\right)\right]\left(\right.$ arene $=\mathrm{C}_{6} \mathrm{H}_{6}, p$-cymene; $\mathrm{PR}_{3}=\mathrm{PPh}_{3}, \mathrm{P}^{\mathrm{i}} \mathrm{Pr}_{3}, \mathrm{PPh}_{2}(\mathrm{OEt})$, $\left.\mathrm{PPh}(\mathrm{OEt})_{2}, \mathrm{P}(\mathrm{OEt})_{3}\right)$ in micellar media (TOF up to $\left.5 \mathrm{~h}^{-1}\right)$ [32] and $\left[\mathrm{RuCl}_{2}\left(\eta^{6}-p\right.\right.$ cymene) $\left.\left(\mathrm{PR}_{3}\right)\right]\left(\mathrm{PR}_{3}=3,5,6\right.$-bicyclophosphite- $\alpha$-D-glucofuranoside-derived ligand) in water (TOF up to $12 \mathrm{~h}^{-1}$ ) [33]. Complexes 20-22 are all able to hydrate nitriles in pure water, within 
the temperature regime $100-150{ }^{\circ} \mathrm{C}$ (classical oil-bath or MW heating), without requirement of any acidic or basic co-catalyst. Best results in terms of activity (TOF and TON up to 127 $\mathrm{h}^{-1}$ and 100 , respectively) were found with the mononuclear compounds $\left[\mathrm{RuCl}_{2}\left(\eta^{6}-\right.\right.$ $\left.\left.\mathrm{C}_{6} \mathrm{Me}_{6}\right)(\mathrm{PTA}-\mathrm{Bn})\right]$ and $\left[\mathrm{RuCl}_{2}\left(\eta^{3}: \eta^{3}-\mathrm{C}_{10} \mathrm{H}_{16}\right)(\mathrm{THPA})\right]$, and the dinuclear one $\left[\left\{\mathrm{RuCl}_{2}\left(\eta^{3}: \eta^{3}-\right.\right.\right.$ $\left.\left.\mathrm{C}_{10} \mathrm{H}_{16}\right)\right\}_{2}(\mu$-THDP)] (22). Almost quantitative conversions of a wide variety of aromatic, heteroaromatic, $\alpha, \beta$-unsaturated and aliphatic nitriles were observed with these systems (5 mol\%) within 1-15 $\mathrm{h}$, and the reactions tolerated common functional groups such as halides, nitro, hydroxy, ethers, thioethers, amino, ketones, aldehyde, esters or alkynes. In addition, after selective crystallization of the final amide, recycling of the aqueous phase containing the active species could also be demonstrated for $\left[\mathrm{RuCl}_{2}\left(\eta^{6}-\mathrm{C}_{6} \mathrm{Me}_{6}\right)(\mathrm{PTA}-\mathrm{Bn})\right]$ [30].

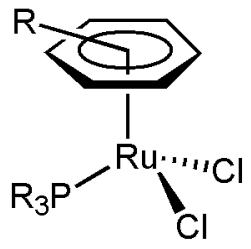

20

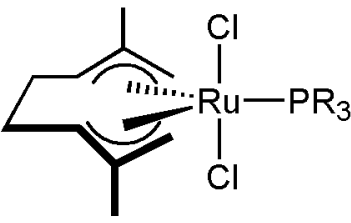

21

arene $=\mathrm{C}_{6} \mathrm{H}_{6}, p$-cymene, $1,3,5-\mathrm{C}_{6} \mathrm{H}_{3} \mathrm{Me}_{3}, \mathrm{C}_{6} \mathrm{Me}_{6}$
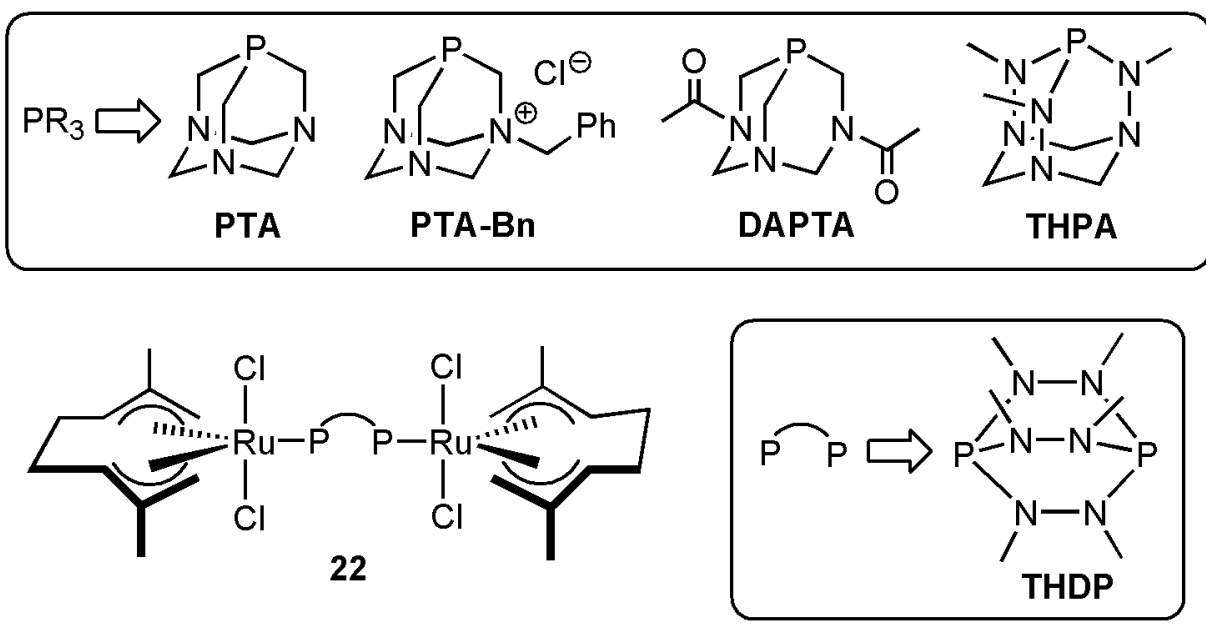

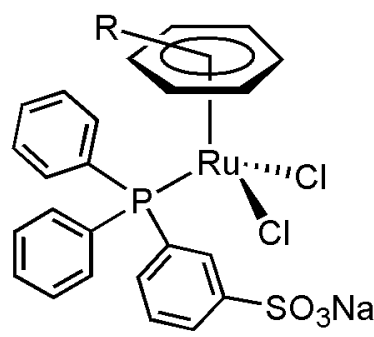

23

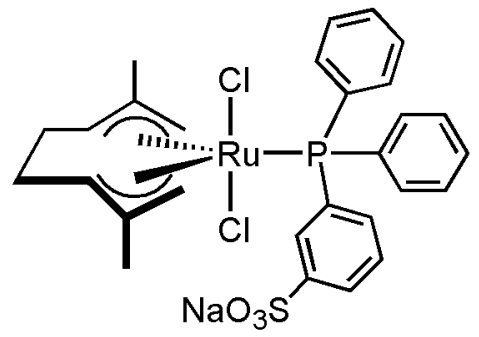

24

arene $=\mathrm{C}_{6} \mathrm{H}_{6}, p$-cymene, $1,3,5-\mathrm{C}_{6} \mathrm{H}_{3} \mathrm{Me}_{3}, \mathrm{C}_{6} \mathrm{Me}_{6}$

Fig. 6. Structure of the water-soluble ruthenium(II) and ruthenium(IV) catalysts 20-24. 
Recycling of $\left[\mathrm{RuCl}_{2}\left(\eta^{6}-\mathrm{C}_{6} \mathrm{Me}_{6}\right)(\mathrm{PTA}-\mathrm{Bn})\right]$ by selective extraction of the amide with ethyl acetate could also be achieved employing a glycerol/water $(1: 1 \mathrm{v} / \mathrm{v})$ mixture as the reaction medium (2 consecutive runs). However, longer reactions times and a higher temperature $\left(160^{\circ} \mathrm{C}\right)$ were in this case needed to attain good conversions [34]. The suitability of glycerol, an emerging green solvent generated as byproduct in the biodiesel industries [35], for nitrile hydration reactions was further confirmed by Romero and co-workers [36]. Thus, employing the octahedral ruthenium(II) complexes $\left[\mathrm{RuCl}_{2}(\mathrm{pypz}-\mathrm{H})(\mathrm{dmso})_{2}\right]$ and $\left[\mathrm{RuCl}_{2}(\mathrm{pz}-\mathrm{H})(\mathrm{dmso})_{3}\right]$ (pypz-H = 2-(3-pyrazolyl)pyridine; pz-H = pyrazole; dmso = dimethyl sulfoxide) as catalysts ( $1 \mathrm{~mol} \%)$, they demonstrated that decrease of activity after recycling is less pronounced in glycerol than in water (up to 4 consecutive runs). However, we must note that faster reactions were in general observed using pure water as solvent (TOF up to 5 $\mathrm{h}^{-1}$ and TON up to 175 at $80^{\circ} \mathrm{C}$ ).

In the same context, the octahedral complex $\left[\mathrm{RuCl}_{2}(\mathrm{PTA})_{4}\right]$, described by Lee and Frost, merits to be highlighted since it featured a good catalytic activity and high functional group tolerance, combined with a superior recycling (more than five times without a significant loss of activity after selective crystallization of the amide product) [37]. Using 5 $\mathrm{mol} \%$ of $\left[\mathrm{RuCl}_{2}(\mathrm{PTA})_{4}\right]$, nearly quantitative conversion of a variety of aromatic, heteroaromatic, aliphatic and $\alpha, \beta$-unsaturated nitriles to their corresponding amides was observed after 7-24 h of heating at $100{ }^{\circ} \mathrm{C}$ in pure water. TOF and TON values of up to $30 \mathrm{~h}^{-1}$ and 22000, respectively, could be reached with this complex in the hydration of benzonitrile at a low ruthenium loading $(0.001 \mathrm{~mol} \%)$. However, we must note that, under these conditions, a maximum conversion of $22 \%$ was observed after 97 days. Interestingly, $\left[\mathrm{RuCl}_{2}(\mathrm{PTA})_{4}\right]$ tolerated the presence of air and the catalytic reactions could be carried under atmospheric conditions (no inert atmosphere required). The arene-ruthenium(II) complex $\mathbf{2 5}$, containing a $\beta$-aminophosphine ligand derived from 1,3,5-triaza-7-phosphaadamantane (PTA), proved to be also active in water under aerobic conditions (Scheme 11) [38]. Thus, using a $5 \mathrm{~mol} \%$ of this complex, various aromatic and aliphatic organonitriles could be transformed into the corresponding amides in moderate to good yields after $24 \mathrm{~h}$ of heating (TOF up to $3 \mathrm{~h}^{-1}$ ). The lifetime and activity of this catalyst was explored in depth for the hydration of benzonitrile to benzamide at various catalyst loadings (from $5 \mathrm{~mol} \%$ to 0.001 mol\%). Interestingly, the TOF increased significantly as the catalyst loading was reduced. In particular, using only $0.001 \mathrm{~mol} \%$ of 25 , TON and TOF values of 97000 and $285 \mathrm{~h}^{-1}$ could be reached with a $97 \%$ conversion after 14 days. These values are higher than those reached with $\left[\mathrm{RuCl}_{2}(\mathrm{PTA})_{4}\right]$. However, despite of its remarkable longevity and activity, we must note 
that 25 presents an important limitation concerning the substrate scope since mixtures of products are formed starting from $\alpha, \beta$-unsaturated nitriles, such as acrylonitrile. As commented by the authors, a cooperative effect of the pendant amino group during catalysis may be behind the high activity shown by complex 25 .
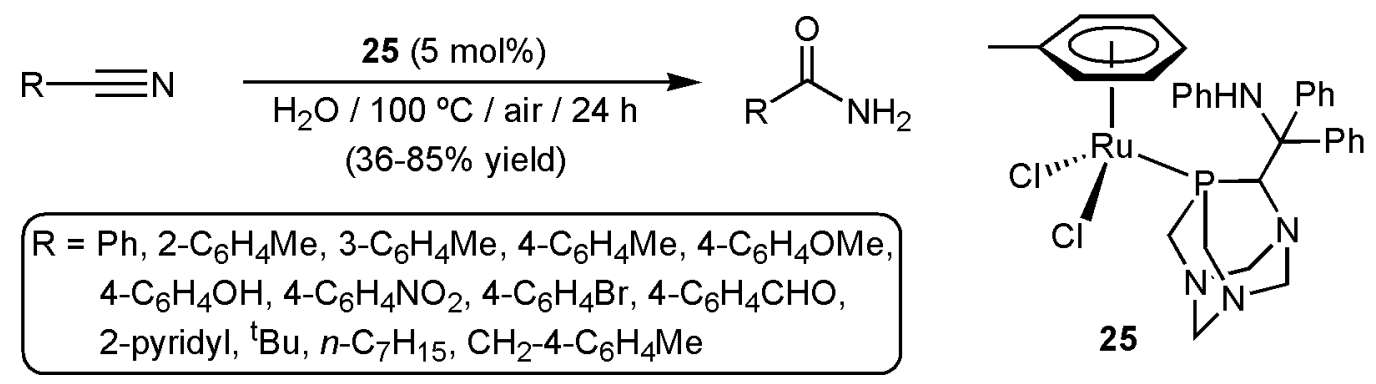

Scheme 11. Catalytic hydration of nitriles in water under aerobic conditions using complex 25.

A significant TON value of 9800 has been recently attained in the catalytic hydration of benzonitrile using the arene-ruthenium(II) complex 26, which contains the water-soluble heterocyclic $P$-donor ligand tris(5-(2-aminothiazolyl))-phosphine trihydrochloride (Fig. 7) [39]. The reaction, performed in pure water with $0.01 \mathrm{~mol} \%$ of $\mathbf{2 6}$, led to the selective formation of the desired benzamide in $98 \%$ GC-yield after 7 days of heating at $100{ }^{\circ} \mathrm{C}$. The generality and great functional group tolerance shown by this catalyst was demonstrated in the selective hydration of a large variety of aromatic, heteroaromatic, aliphatic and $\alpha, \beta$ unsaturated nitriles. Thus, using $3 \mathrm{~mol} \%$ of 26, they could be converted into the corresponding primary amides in high isolated yields $(\geq 78 \%)$ and after short reaction periods $\left(0.5-7 \mathrm{~h}\right.$; TOF up to $\left.66 \mathrm{~h}^{-1}\right)$. In addition, the high solubility of complex 26 in water allowed a facile amide product separation (by selective crystallization), and the effective reuse of the remaining aqueous solution containing the catalyst (up to five consecutive runs). On the other hand, the utility of complex $\mathbf{2 6}$ in promoting the formation of primary amides in water by catalytic rearrangement of aldoximes and direct coupling of aldehydes with hydroxylamine was also demonstrated [39].

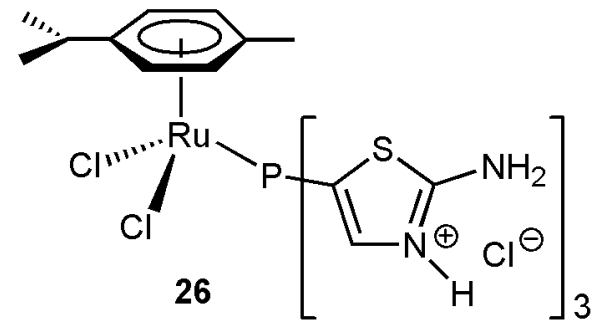

Fig. 7. Structure of the water-soluble arene-ruthenium(II) complex 26. 
Despite the remarkable activity in water shown by complexes $\mathbf{2 0 - 2 2},\left[\mathrm{RuCl}_{2}(\mathrm{PTA})_{4}\right]$ and 25-26, the requirement of rather elaborated phosphine ligands makes them unappealing face to practical applications. In this context, the arene-ruthenium(II) complexes $\left[\mathrm{RuCl}_{2}\left(\eta^{6}-\right.\right.$ arene) $\left.\left\{\mathrm{P}\left(\mathrm{NMe}_{2}\right)_{3}\right\}\right]$ (arene $=\mathrm{C}_{6} \mathrm{H}_{6}, \quad p$-cymene, 1,3,5- $\mathrm{C}_{6} \mathrm{H}_{3} \mathrm{Me}_{3}, \mathrm{C}_{6} \mathrm{Me}_{6}$ ), described by Cadierno, Crochet and co-workers [40], represent more simple and competitive alternatives since they make use of the commercially available and inexpensive ligand tris(dimethylamino)phosphine. All these complexes are able to operate in pure water under neutral conditions. In particular, the hexamethylbenzene derivative $\left[\mathrm{RuCl}_{2}\left(\eta^{6}-\right.\right.$ $\left.\left.\mathrm{C}_{6} \mathrm{Me}_{6}\right)\left\{\mathrm{P}\left(\mathrm{NMe}_{2}\right)_{3}\right\}\right]$ (27) proved to be highly effective, providing the desired amides from a wide range of organonitriles in excellent yields and short times (TOF values up to $11400 \mathrm{~h}^{-1}$ could be reached at $150{ }^{\circ} \mathrm{C}$ under MW irradiation) [40,41]. Remarkably, the corresponding hexamethylbenzene derivatives proved to be also the most active within the series of complexes 20 discussed above (Fig. 6) [30]. Since an increase of the steric bulk of the $\eta^{6}$ arene ligand would lead to an increase in the rate of ligand dissociation, the rate-determining step in these hydration reactions may be the dissociation of the amide from the metal. Additionally, having a more electron-donating $\eta^{6}$-arene ligand would make the metal center less Lewis acidic, which would make the ruthenium-amide bond weaker.

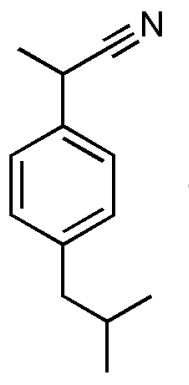

28

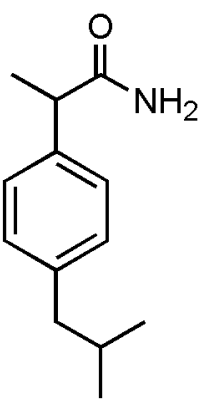

29

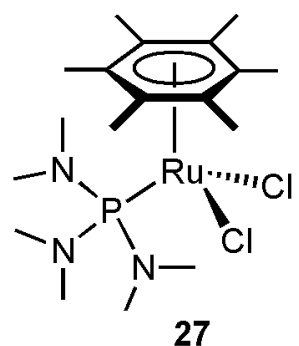

27

Scheme 12. Catalytic synthesis of ibuprofenamide 29 using complex $\left[\mathrm{RuCl}_{2}\left(\eta^{6}-\mathrm{C}_{6} \mathrm{Me}_{6}\right)\left\{\mathrm{P}\left(\mathrm{NMe}_{2}\right)_{3}\right\}\right](\mathbf{2 7})$.

Taking advantage of the remarkable activity of $\left[\mathrm{RuCl}_{2}\left(\eta^{6}-\mathrm{C}_{6} \mathrm{Me}_{6}\right)\left\{\mathrm{P}\left(\mathrm{NMe}_{2}\right)_{3}\right\}\right](27)$, an efficient and practical synthesis of the non-steroidal anti-inflammatory drug ibuprofenamide 29 by catalytic hydration of 2-(4-isobutylphenyl)propionitrile 28 could be developed (Scheme 12) [40]. Complex 27 proved to be also useful for the one-pot conversion of $\delta$ ketonitrile to ene-lactams in water [40], thus representing a water-soluble substitute of the Murahashi's catalyst $\left[\mathrm{RuH}_{2}\left(\mathrm{PPh}_{3}\right)_{4}\right]$ (Scheme 4) [13]. However, we must note that, despite 
the remarkable activity shown by $\left[\mathrm{RuCl}_{2}\left(\eta^{6}-\mathrm{C}_{6} \mathrm{Me}_{6}\right)\left\{\mathrm{P}\left(\mathrm{NMe}_{2}\right)_{3}\right\}\right]$ (27), the TON values reached with this catalyst were only modest (up to 196) due to its progressive decomposition in the reaction media. Such decomposition generates in solution the less active dimethylamine-ruthenium(II) complex $\left[\mathrm{RuCl}_{2}\left(\eta^{6}-\mathrm{C}_{6} \mathrm{Me}_{6}\right)\left(\mathrm{NHMe}_{2}\right)\right]$ by hydrolysis of the P-N bonds and displacement of the resulting phosphorus species $\left(\mathrm{P}\left(\mathrm{NMe}_{2}\right)_{3-\mathrm{x}}(\mathrm{OH})_{\mathrm{x}} ; \mathrm{x}=1,2\right.$ or 3$)$ [40].

Subsequent studies by Tyler and co-workers revealed the utility of complexes $\left[\mathrm{RuCl}_{2}\left(\eta^{6}\right.\right.$-arene $\left.)\left\{\mathrm{P}\left(\mathrm{NMe}_{2}\right)_{3}\right\}\right]$ to promote the challenging hydration of $\alpha$-hydroxynitriles (cyanohydrins) to the corresponding $\alpha$-hydroxyamides [42]. Homogeneous catalysts, including the Parkin's one (Fig. 1) [43], usually show a extremely low reactivity towards this class of nitriles due to their poisoning by cyanide, a species that is generated in solution by partial decomposition of the cyanohydrins. As shown in Scheme 13, using $5 \mathrm{~mol} \%$ of $\left[\mathrm{RuCl}_{2}\left(\eta^{6}\right.\right.$-p-cymene) $\left.\left\{\mathrm{P}\left(\mathrm{NMe}_{2}\right)_{3}\right\}\right](\mathbf{3 0})$ as catalyst, and running the catalytic reactions within the $\mathrm{pH}$ range 3.5-8.5 to minimize the decomposition of the substrates into the corresponding aldehydes and $\mathrm{HCN}$, complete conversion of glycolonitrile $(\mathrm{R}=\mathrm{H})$ and lactonitrile $(\mathrm{R}=\mathrm{Me})$ could be achieved at room temperature.

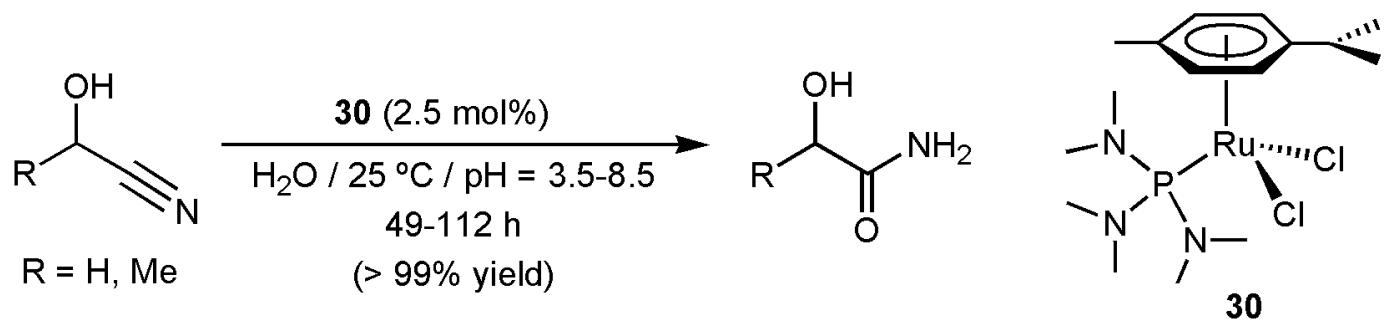

Scheme 13. Catalytic hydration of cyanohydrins using complex $\left[\mathrm{RuCl}_{2}\left(\eta^{6}-p\right.\right.$-cymene $\left.)\left\{\mathrm{P}\left(\mathrm{NMe}_{2}\right)_{3}\right\}\right](\mathbf{3 0})$.

The effectiveness shown by these readily accessible $\left[\mathrm{RuCl}_{2}\left(\eta^{6}\right.\right.$-arene $\left.)\left\{\mathrm{P}\left(\mathrm{NMe}_{2}\right)_{3}\right\}\right]$ complexes in nitrile hydration processes is ascribed to the excellent hydrogen bond accepting properties of $\mathrm{P}\left(\mathrm{NMe}_{2}\right)_{3}$, which activates the water molecule by $\mathrm{H}$-bonding thus facilitating its approach and addition to the coordinated nitrile (Fig. 8). Such a cooperative effect was supported by DFT calculations. In a more recent article, Tyler and co-workers described faster glycolonitrile and lactonitrile hydrations employing the related phosphinite-Ru(II) complex $\left[\mathrm{RuCl}_{2}\left(\eta^{6}-p\right.\right.$-cymene) $\left.\left\{\mathrm{PMe}_{2}(\mathrm{OH})\right\}\right]$ (quantitative transformations after 6-17 $\mathrm{h}$ under the conditions indicated in Scheme 13) [44,45]. H-bonding between the $\mathrm{OH}$ group and the incoming water molecule in the secondary coordination sphere of the catalyst was again evidenced by DFT calculations. Despite these relevant results, that represent a benchmark for 
future studies in the field, we must note that complexes $\left[\mathrm{RuCl}_{2}\left(\eta^{6}-p\right.\right.$-cymene $)\left\{\mathrm{P}\left(\mathrm{NMe}_{2}\right)_{3}\right]$ (30) and $\left[\mathrm{RuCl}_{2}\left(\eta^{6}-p\right.\right.$-cymene) $\left.\left\{\mathrm{PMe}_{2}(\mathrm{OH})\right\}\right]$ are susceptible to cyanide poisoning. This fact explains the poor conversions observed in the hydration of acetone cyanohydrin (up to 15\%), a substrate particularly prone to decompose into acetone and hydrogen cyanide.



Fig. 8. The cooperative effect of the $\mathrm{P}\left(\mathrm{NMe}_{2}\right)_{3}$ ligand.

In addition to all the examples commented above, other hydration processes catalyzed by homogeneous ruthenium catalysts described in the literature include (Scheme 14): (i) The hydration of the benzoxazolylacetonitrile 31 by dimer $\left[\left\{\mathrm{RuCl}(\mu-\mathrm{Cl})\left(\eta^{6}-p \text {-cymene }\right)\right\}_{2}\right]$, which allowed the synthesis of the benzoxazolylacetamide 32 in high yield [46]. (ii) The hydration of the chloroacetonitriles $\mathbf{3 3}$ employing the mononuclear arene-ruthenium(II) complexes $\mathbf{3 5}$ containing different pyranone- and pyridinone-based ligands [47]. The corresponding chloroacetamides 34, a particular class of compounds that exhibit biological properties and are widely used as building blocks in preparative organic chemistry [48], could be obtained in modest to high yields employing low ruthenium loadings (0.1-0.2 mol\%) and pure water as solvent (TOF up to $39 \mathrm{~h}^{-1}$ and TON up to 562). (iii) The asymmetric hydration of the prochiral dinitrile $\alpha$-benzyl- $\alpha$-methylmalononitrile $\mathbf{3 6}$ by the optically active catalysts $\mathbf{3 8}$, which led to cyanoamide 37 in modest yields and low enantiomeric excesses [49]. And, (iv) the selective transformation, in water at $\mathrm{pH} 10.5$, of acetonitrile into acetamide by means of the octahedral dicationic $\mathrm{Ru}(\mathrm{II})$ complex $\left[\mathrm{Ru}\left(\mathrm{H}_{2} \mathrm{O}\right)(\mathrm{NCMe})_{4}\left(\mathrm{P}^{\mathrm{i}} \mathrm{Pr}_{3}\right)\right]\left[\mathrm{BF}_{4}\right]_{2}$ (initial TOF $=50$ $\left.\mathrm{h}^{-1}\right)$ [50]. At $\mathrm{pH}>9$ this complex is deprotonated to form $\left[\mathrm{Ru}(\mathrm{OH})(\mathrm{NCMe})_{4}\left(\mathrm{P}^{\mathrm{i}} \mathrm{Pr}_{3}\right)\right]\left[\mathrm{BF}_{4}\right]$, which gradually evolves into the bidentate acetamido derivative $\left[\operatorname{Ru}\left\{\kappa^{2}-(N, O)\right.\right.$ $\left.\mathrm{NH}(\mathrm{CO}) \mathrm{Me}\}(\mathrm{NCMe})_{3}\left(\mathrm{P}^{\mathrm{i}} \mathrm{Pr}_{3}\right)\right]\left[\mathrm{BF}_{4}\right]$ by intramolecular nucleophilic attack of the hydroxide on one of the coordinated nitrile ligands. This conversion was proposed to be part of the catalytic cycle [51]. 

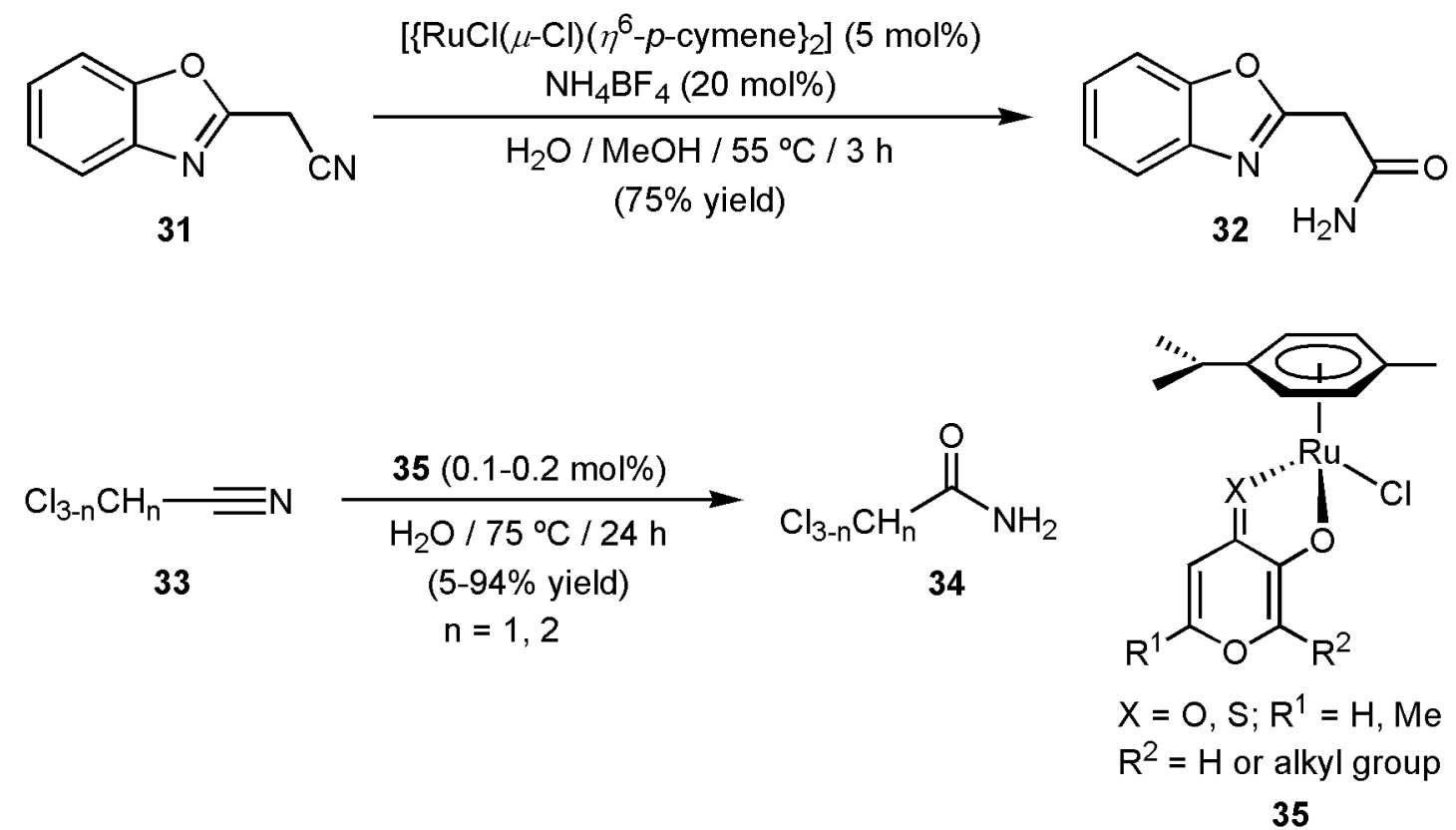<smiles>CC(C#N)(C#N)Cc1ccccc1</smiles>

36

<smiles>C[C@@](C#N)(Cc1ccccc1)C(N)=O</smiles>

37


$\mathrm{R}=\mathrm{Ms}, \mathrm{Ts}$

38

Scheme 14. Some nitriles hydration reactions catalyzed by ruthenium(II) complexes.

Quite recently, in an attempt of mimicking the active sites of the iron-containing NHase enzymes [5], C. A. Grapperhaus and co-workers have also described the catalytic hydration of benzonitrile using the octahedral ruthenium(II) derivatives 39 (Fig. 9) [52]. These complexes were able to operate in neat substrate/water mixtures, without the requirement of added base or buffer, generating benzamide in a selective manner albeit in very low yields $(<$ 10\%; TON and TOF values up to 242 and $13 \mathrm{~h}^{-1}$, respectively, at $124{ }^{\circ} \mathrm{C}$ using $c a .10^{-3} \mathrm{~mol} \%$ of 39). During this study, it was found that those catalysts with an oxidized sulfur environment were less susceptible to product inhibition, increasing the catalytic efficiency at low nitrile/water ratios. 

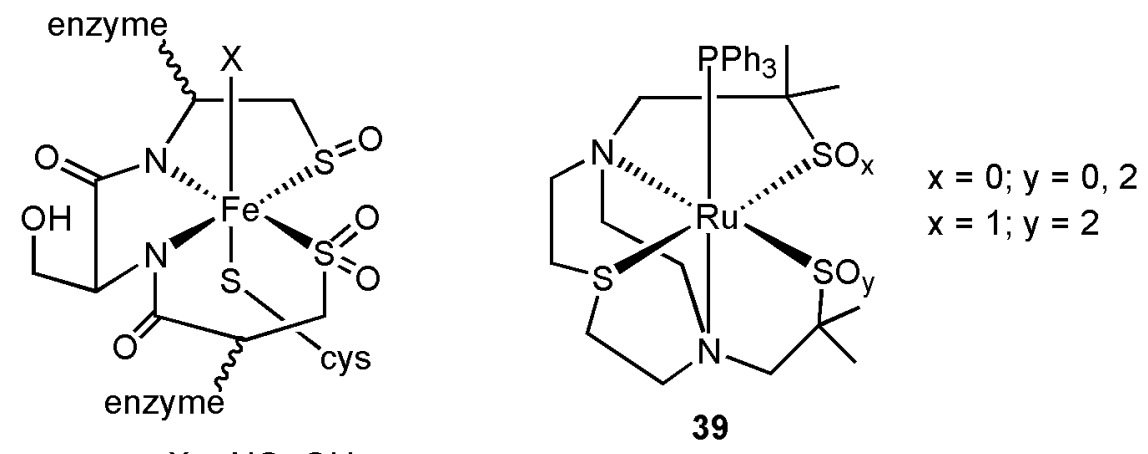

Fig. 9. Structure of the active sites of Fe-containing NHase enzymes and complexes 39.

\section{Heterogeneous ruthenium-based catalysts}

Despite the enormous interest for industry of heterogeneous catalysts due to their easier handling, higher stability, easier recovery and reusability, heterogeneous ruthenium-based systems for nitrile hydration reactions have been comparatively much less developed than the homogeneous ones. In this context, the use of ruthenium supported on carbon $(\mathrm{Ru} / \mathrm{C})$ [53] and alumina $\left(\mathrm{Ru} / \mathrm{Al}_{2} \mathrm{O}_{3}\right)$ [54], as well ruthenium nanoparticles combined with oxygencontaining copper compounds [55], has been described in a series of Japanese patents. All of them were active and selective towards amide formation under temperatures regimes of 80$135^{\circ} \mathrm{C}$. However, little can be said about the scope, activity and recyclability of these systems given the scarce information included in the documents. Quite recently, Kumar and Das reported the preparation of ruthenium nanoparticles supported on the polystyrene ion exchange resin Amberlite IRA 900 chloride, which proved to be catalytically active under microwave irradiation [56]. Thus, performing the reactions in water at $130{ }^{\circ} \mathrm{C}$ with a $\mathrm{Ru}$ loading of $3 \mathrm{~mol} \%$, a wide range of aromatic, heteroaromatic, aliphatic and $\alpha, \beta$-unsaturated nitriles were efficiently and selectively converted to their corresponding primary amides in high yields (60-88\%) after $1-2 \mathrm{~h}$ of irradiation (TOF up to $33 \mathrm{~h}^{-1}$ ). In addition, after extraction of the amide products with ethyl acetate, the catalytic system could be reused up to ten times without significant loss of activity and selectivity (accumulated TON of $c a$. 300). Effective reuse of a Nafion resin-supported ruthenium catalyst (up to six cycles; accumulated TON of 155) has also been described by Prakash, Mathew and workers (Scheme 15) [57]. This catalytic system, which was generated from Nafion-K by ionexchange with anhydrous $\mathrm{RuCl}_{3}$ in 1,2-dichloroethane, proved to be operative with a large variety of aromatic and heteroaromatic nitriles in water at $175^{\circ} \mathrm{C}$, employing a metal loading of $4 \mathrm{~mol} \%$ (TOF up to $2 \mathrm{~h}^{-1}$ ). Separation of the catalyst from the amide product was held in 
this case by centrifugation of the crude reaction mixture. Once the catalyst was recovered, the amides were isolated by evaporation of the aqueous solution and further chromatographic purification.
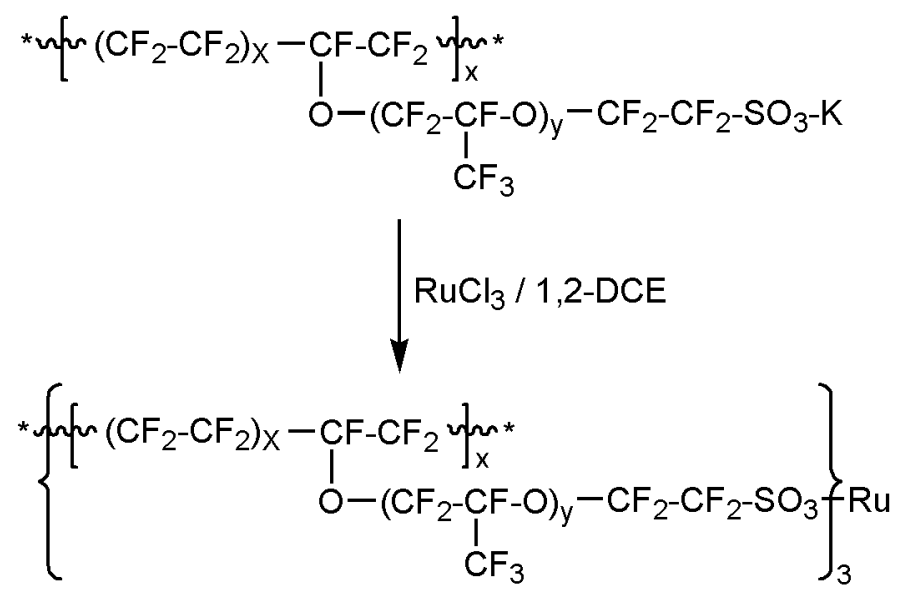

Nafion-Ru

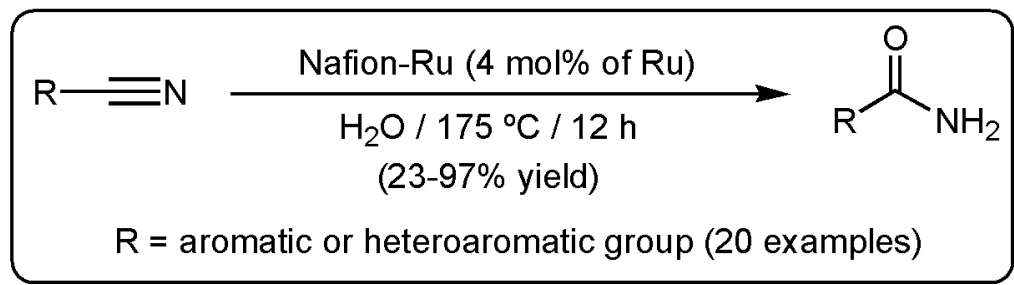

Scheme 15. Catalytic hydration of nitriles employing Nafion-Ru as catalyst.

Efficient and selective hydration of a number of organonitriles, in water at $140{ }^{\circ} \mathrm{C}$, was described by Mizuno and co-workers employing ruthenium hydroxide supported on alumina $\left(\mathrm{Ru}(\mathrm{OH})_{\mathrm{X}} / \mathrm{Al}_{2} \mathrm{O}_{3}\right)$ as catalyst (TOF and TON values up to $13 \mathrm{~h}^{-1}$ and 234, respectively) [58]. Worthy of note, using $\mathrm{Ru}(\mathrm{OH})_{\mathrm{x}} / \mathrm{Al}_{2} \mathrm{O}_{3}$, a totally organic solvent free protocol was developed since the solid catalyst can be easily separated from the reaction mixture by hot filtration at $90{ }^{\circ} \mathrm{C}$, and the amides crystallize in pure form from the filtrate upon cooling at $0{ }^{\circ} \mathrm{C}$. Furthermore, the heterogeneous $\mathrm{Ru}(\mathrm{OH})_{\mathrm{x}} / \mathrm{Al}_{2} \mathrm{O}_{3}$ system could be reused two times without any change in the activity. In the hydration of methylbenzonitriles, the lower reaction rate observed with $o$-methylbenzonitrile relative to its meta- and para-substituted counterparts indicated a marked steric effect, which was not found when the same hydration reactions were performed with $\mathrm{NaOH}$. These observations strongly suggest that the nitrile coordinates to the ruthenium center on the surface of $\mathrm{Ru}(\mathrm{OH})_{\mathrm{x}} / \mathrm{Al}_{2} \mathrm{O}_{3}$, and that the hydration reaction proceeds via attack of a ruthenium hydroxide species on the coordinated nitrile (Scheme 16) [51]. On the other hand, $\mathrm{Ru}(\mathrm{OH})_{\mathrm{x}} / \mathrm{Al}_{2} \mathrm{O}_{3}$ was also able to promote the formation of primary 
amides in water by catalytic aerobic oxidation of primary amines [59] and azides [60]. In these processes, the hydration of an in situ formed nitrile was proposed as a key step in the corresponding catalytic cycles.



Scheme 16. Proposed mechanism for the $\mathrm{Ru}(\mathrm{OH})_{\mathrm{x}} / \mathrm{Al}_{2} \mathrm{O}_{3}$-catalyzed hydration of nitriles.

Organic solvents-free protocols for the selective conversion of nitriles to amides have also been developed by means of ruthenium hydroxide supported on dopaminefunctionalized $\mathrm{Fe}_{3} \mathrm{O}_{4}$ nanoparticles 40 [61], and $\mathrm{Ru}(\mathrm{OH})_{\mathrm{x}}$ nanoparticles 41 [62] and a bifunctional ruthenium(II) complex 42 [63] supported on silica-coated $\mathrm{Fe}_{3} \mathrm{O}_{4}$ nanoparticles (Fig. 10).

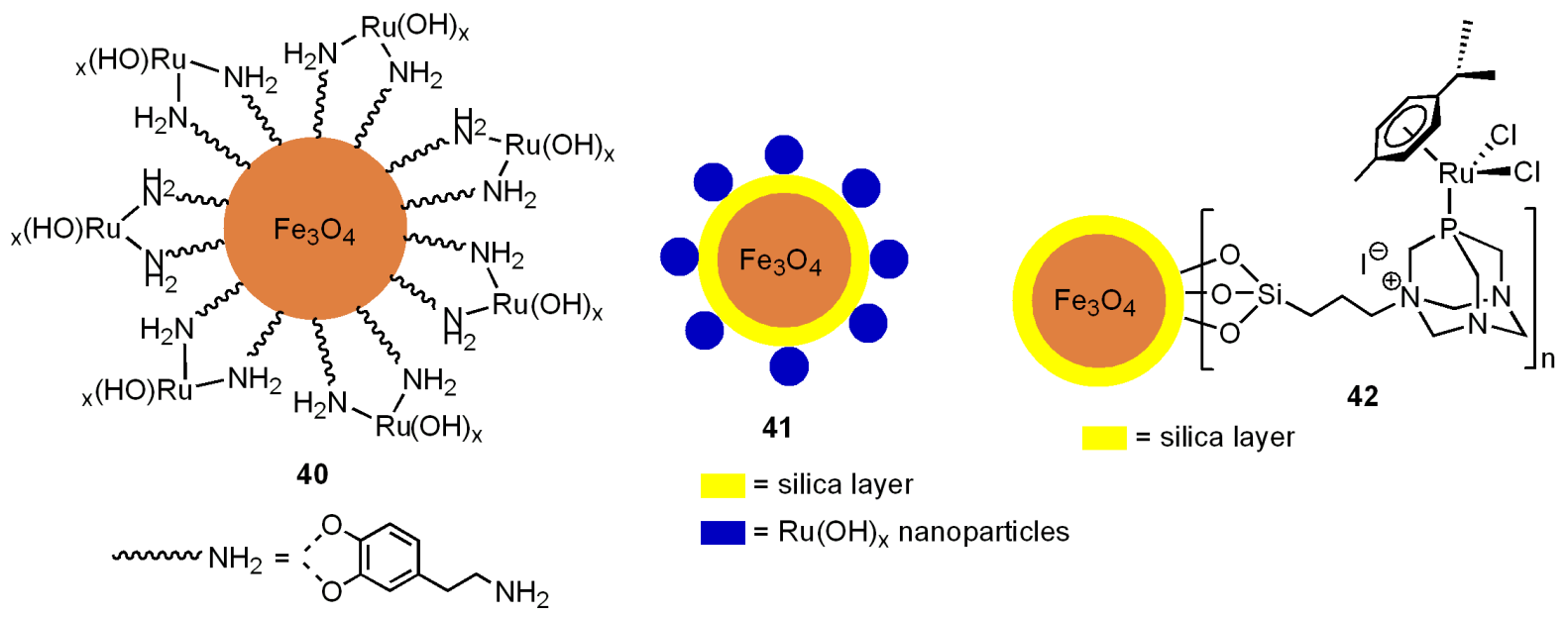

Fig. 10. Structure of the ruthenium-based nanocatalysts 40-42.

All these nanocatalysts showed excellent activities (TOFs up to $170 \mathrm{~h}^{-1}$ ) and selectivities for a broad range of activated and inactivated benzonitriles, as well as heteroaromatic, aliphatic and $\alpha, \beta$-unsaturated nitriles, leading to the corresponding primary amides in high yields (70-95\%) after 0.5-7 h of MW irradiation at $100-150{ }^{\circ} \mathrm{C}$ in pure water. 
None of them needed the use of acidic or basic co-catalysts, all showed a remarkable functional group tolerance, and no overhydrolysis to carboxylic acids was observed with them. Noteworthy, the selective mono and dihydration of dinitriles could be conveniently achieved using 42 just by controlling the time of MW irradiation (Scheme 17) [63]. Because the super-paramagnetic nature of the $\mathrm{Fe}_{3} \mathrm{O}_{4}$ support, all these nanocatalysts could be easily separated from the reaction products with the help of an external magnet, and recycled up to three (40 and 41) or six (42) times (cumulated TON up to 358). Crystals of the amides precipitated by cooling down the remaining aqueous solution and were isolated by simple decantation/filtration.

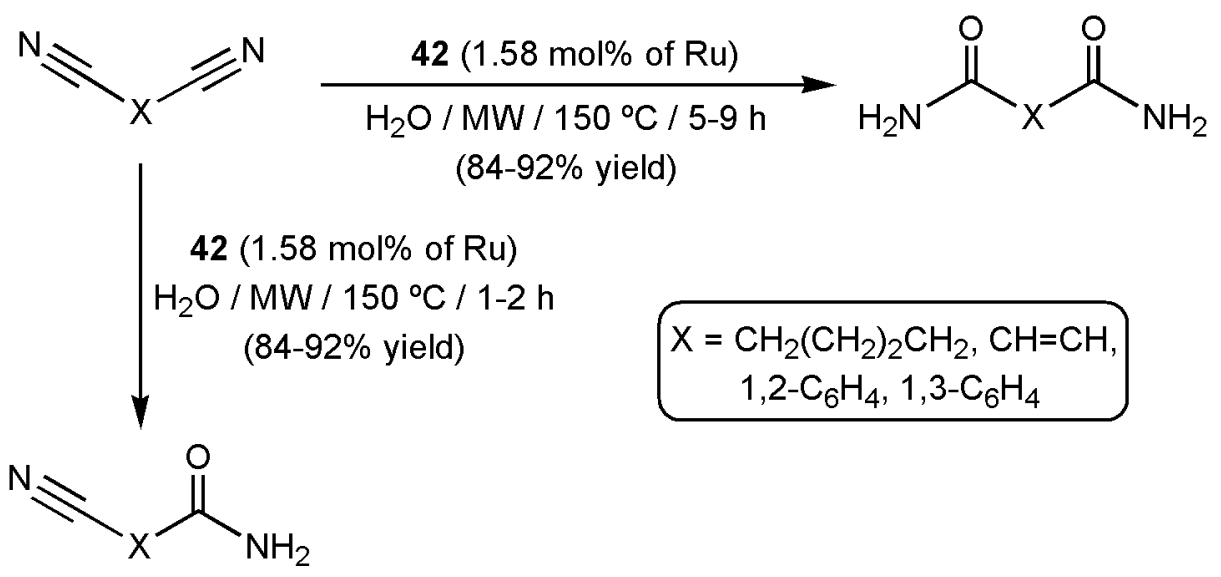

Scheme 17. Catalytic hydration of dinitriles employing the nanocatalyst $\mathbf{4 2}$.

Ruthenium-substituted hydroxyapatite $\left((\mathrm{RuCl})_{2} \mathrm{Ca}_{8}\left(\mathrm{PO}_{4}\right)_{6}(\mathrm{OH})_{2}\right)$ was also employed by Kaneda and co-workers to promote the selective hydration of various kinds of nitriles in water at $150{ }^{\circ} \mathrm{C}$. Very modest activities were observed with this heterogeneous system (TOF up to $0.2 \mathrm{~h}^{-1}$ ) [64].

\section{Conclusions}

The development of metal catalysts for the hydration of nitriles to amides is a field that has received considerable attention in the past two decades. In this review article we have discussed the specific contribution of ruthenium compounds to the process. As the reader will have noticed, many homogeneous ruthenium catalysts have been developed in the last years. Remarkably, some of them allow to carry out this synthetically useful reaction directly in water, without the assistance of any acidic or basic additive, under relatively mild conditions and with a high functional group compatibility. The greatest advances in the field 
have been achieved through the concept of "bifunctional catalysis" where the ligands attached to ruthenium play a key role in the activation of the water nucleophile. The TOF and TON values reached with this type of catalysts are the highest described so far for this catalytic transformation. Promising results have also been described in the challenging hydration of cyanohydrins, a particular class of nitriles that remains elusive towards catalytic hydration. The results achieved can be surely improved through the design of new bifunctional systems. Concerning heterogenous ruthenium catalysts, although some relevant results have obtained employing magnetic nanocatalysts, the field remains almost unexplored. We hope that this article will serve as inspiration for future work in the area, which offer with many opportunities for the new discoveries.

\section{Acknowledgements}

Financial support by the Spanish MINECO (projects CTQ2010-14796/BQU and CSD2007-00006) is gratefully acknowledged. J.F. and E.T.-M. thank MECD of Spain and the European Social Fund for the award of FPU grants.

\section{References}

[1] See, for example: (a) J. Zabicky (Ed.), The Chemistry of Amides, John Wiley \& Sons, New York, 1970; (b) A. Greenberg, C. M. Breneman, J. F. Liebman (Eds.), The Amide Linkage: Structural Significance in Chemistry, Biochemistry and Materials Science, John Wiley \& Sons, New York, 2000; (c) B. L. Deopura, B. Gupta, M. Joshi, R. Alagirusami (Eds.), Polyesters and Polyamides, CRC Press, Boca Raton, 2008; (d) I. Johansson, Kirk-Othmer Encyclopedia of Chemical Technology, John Wiley \& Sons, New York, 2004, Vol. 2, pp 442-463.

[2] (a) C. A. G. N. Montalbetti, V. Falque, Tetrahedron 61 (2005) 10827-10852; (b) P. D. Bailey, T. J. Mills, R. Pettecrew, R. A. Price, in A. R. Katritzky, R. J. K. Taylor (Eds.), Comprehensive Organic Functional Group Transformations II, Elsevier, Oxford, 2005, Vol. 5, pp 201-294; (c) D. Dopp, H. Dopp (Eds.), Methoden Org. Chem. (Houben Weyl), Thieme Verlag, Stuttgart, 1985, Vol. E5(2), pp 1024-1031.

[3] E. Valeur, M. Bradley, Chem. Soc. Rev. 38 (2009) 606-631.

[4] For reviews covering innovative amide bond forming reactions, see: (a) C. L. Allen, J. M. J. Williams, Chem. Soc. Rev. 40 (2011) 3405-3415; (b) V. R. Pattabiraman, J. W. 
Bode, Nature 480 (2011) 471-479; (c) R. García-Álvarez, P. Crochet, V. Cadierno, Green Chem. 15 (2013) 46-66; (d) J. W. Bode, Top. Organomet. Chem. 44 (2013) 1334; (e) C. Singh, V. Kumar, U. Sharma, N. Kumar, B. Singh, Curr. Org. Chem. 10 (2013) 241-264.

[5] For selected reviews, see: (a) M. Kobayashi, S. Shimizu, Curr. Opin. Chem. Biol. 4 (2000) 95-102; (b) I. Endo, M. Nojori, M. Tsujimura, M. Nakasako, S. Nagashima, M. Yohda, M. Odaka, J. Inorg. Biochem. 83 (2001) 247-253; (c) V. Mylerová, L. Martínková, Curr. Org. Chem. 7 (2003) 1279-1295; (d) J. A. Kovacs, Chem. Rev. 104 (2004) 825-848; (e) G. De Santis, R. Di Cosimo, in J. Tao, G.-Q. Lin, A. Liese (Eds.), Biocatalysis for the Pharmaceutical Industry: Discovery, Development and Manufacturing, Wiley-VCH, Weinheim, 2009, pp 153-181; (f) S. Prasad, T. C. Bhalla, Biotechnol. Adv. 28 (2010) 725-741; (g) P. W. Ramteke, N. G. Maurice, B. Joseph, B. J. Wadher, Biotechnol. Appl. Biochem. in press (DOI: 10.1002/bab.1139).

[6] (a) H. Yamada, M. Kobayashi, Biosci. Biotech. Biochem. 60 (1996) 1391-1400; (b) S. van Pelt, F. van Rantwijk, R. A. Sheldon, in Focus in Catalysis Applications (supplement to Chimica Oggi/Chemistry Today), Teknoscience Srl, Milano, 2008, Vol. 26, pp 2-4; (c) S. Sanchez, A. L. Demain, Org. Process Res. Dev. 15 (2011) 224-230; (d) B. Li, J. Su, J. Tao, Org. Process Res. Dev. 15 (2011) 291-293; (e) J. Tao, J.-H. Xu, Curr. Opin. Chem. Biol. 13 (2009) 43-50.

[7] For reviews, see: (a) A. W. Parkins, Platinum Metals Rev. 40 (1996) 169-174; (b) V. Y. Kukushkin, A. J. L. Pombeiro, Chem. Rev. 102 (2002) 1771-1802; (c) N. A. Bokach, V. Y. Kukushkin, Russ. Chem. Rev. 74 (2005) 153-170; (d) V. Y. Kukushkin, A. J. L. Pombeiro, Inorg. Chim. Acta 358 (2005) 1-21; (e) T. J. Ahmed, S. M. M. Knapp, D. R. Tyler, Coord. Chem. Rev. 255 (2011) 949-974.

[8] For recent examples of heterogeneous catalysts, see: (a) T. Mitsudome, Y. Mikani, H. Mori, S. Arita, T. Mizugaki, K. Jitsukawa, K. Kaneda, Chem. Commun. (2009) 32583260; (b) M. Tamura, H. Wakasugi, K.-I. Shimizu, A. Satsuma, Chem. Eur. J. 17 (2011) 11428-11431; (c) A. Y. Kim, H. S. Bae, S. Park, S. Park, K. H. Park, Catal. Lett. 141 (2011) 685-690; (d) Y.-M. Liu, L. He, M.-M. Wang, Y. Cao, H.-Y. He, K.N. Fan, ChemSusChem 5 (2012) 1392-1396; (e) K.-I. Shimizu, N. Imaiida, K. Sawabe, A. Satsuma, Appl. Catal. A: Gen. 421-422 (2012) 114-120; (f) T. Subramanian, K. Pitchumani, Catal. Commun. 29 (2012) 109-113; (g) K.-I. Shimizu, T. Kubo, A. Satsuma, T. Kamachi, K. Yoshizawa, ACS Catal. 2 (2012) 2467-2474; (h) Y. Gangarajula, B. Gopal, Chem. Lett. 41 (2012) 101-103; (i) T. Hirano, K. Uehara, K. 
Kamata, N. Mizuno, J. Am. Chem. Soc. 134 (2012) 6425-6433; (j) M. Tamura, A. Satsuma, K.-I. Shimizu, Catal. Sci. Technol. 3 (2013) 1386-1393.

[9] (a) T. Ghaffar, A. W. Parkins, Tetrahedron Lett. 36 (1995) 8657-8660; (b) T. Ghaffar, A. W. Parkins, J. Mol. Catal. A: Chem. 160 (2000) 249-261.

[10] (a) J. Akisanya, A. W. Parkins, J. W. Steed, Org. Process Res. Dev. 2 (1998) 274-276;

(b) X.-B. Jiang, A. J. Minnaard, B. L. Feringa, J. G. de Vries, J. Org. Chem. 69 (2004) 2327-2331; (c) J. C. Rech, P. E. Floreancig, Org. Lett. 7 (2005) 5175-5178; (d) S. B. Herzon, A. G. Myers, J. Am. Chem. Soc. 127 (2005) 5342-5344; (e) X. Jiang, J. García-Fontanet, J. K. De Brabander, J. Am. Chem. Soc. 127 (2005) 11254-11255; (f) R. Grigg, A. Hasakunpaisarn, C. Kilner, B. Kongkathip, N. Kongkathip, A. Pettman, V. Sridharan, Tetrahedron 61 (2005) 9356-9367; (g) T. J. Greshock, R. L. Funk, Org. Lett. 8 (2006) 2643-2645; (h) Y. Wang, X. Liu, L. Deng, J. Am. Chem. Soc. 128 (2006) 3928-3930; (i) X. Jiang, N. Williams, J. K. De Brabander, Org. Lett. 9 (2007) 227-230; (j) B. Wang, F. Wu, Y. Wang, X. Liu, L. Deng, J. Am. Chem. Soc. 129 (2007) 768769; (k) T. Kan, Y. Kawamoto, T. Asakawa, T. Furuta, T. Fukuyama, Org. Lett. 10 (2008) 169-171; (1) J. R. Falck, S. Gao, R. N. Prasad, S. R. Koduru, Bioorg. Med. Chem. Lett. 18 (2008) 1768-1771; (m) R. A. Jones, M. J. Krische, Org. Lett. 11 (2009) 1849-1851; (n) M. Kurosu, K. Li, D. C. Crick, Org. Lett. 11 (2009) 2393-2396; (o) L. E. Brown, Y. R. Landaverry, J. R. Davies, K. A. Milinkevich, S. Ast, J. S. Carlson, A. G. Oliver, J. P. Konopelski, J. Org. Chem. 74 (2009) 5405-5410; (p) F. d. J. Cortez, R. Sarpong, Org. Lett. 12 (2010) 1428-1431; (q) C.-K. Mai, M. F. Sammons, T. Sammakia, Angew. Chem. Int. Ed. 49 (2010) 2397-2400; (r) T. A. Brugel, R. W. Smith, M. Balestra, C. Becker, T. Daniels, G. M. Koether, S. M. Throner, L. M. Panko, D. G. Brown, R. Liu, J. Gordon, M. F. Peters, Bioorg. Med. Chem. Lett. 20 (2010) 5405-5410; (s) M. K. M. Tun, D.-J. Wüstmann, S. B. Herzon, Chem. Sci. 2 (2011) 2251-2253; (t) L. Yao, B. Pitta, P. C. Ravikumar, M. Purzycki, F. F. Fleming, J. Org. Chem. 77 (2012) 3651-3657; (u) R. S. Andrews, A. J. Becker, M. R. Gagné, Angew. Chem. Int. Ed. 51 (2012) 4140-4143; (v) Y. Feng, X. Jiang, J. K. De Brabander, J. Am. Chem. Soc. 134 (2012) 17083-17093; (w) E. d. J. Cortez, D. Lapointe, A. M. Hamlin, E. M. Simmons, R. Sarpong, Tetrahedron 69 (2013) 5665-5676.

[11] (a) S.-I. Murahashi (Ed.), Ruthenium in Organic Synthesis, Wiley-VCH, Weinheim, 2004; (b) C. Bruneau, P. H. Dixneuf (Eds.) Ruthenium Catalysts and Fine Chemistry, Springer, Berlin, 2004; (c) W. P. Griffith, Ruthenium Oxidation Complexes: Their Uses as Homogeneous Organic Catalysts, Springer, Dordrecht, 2011. 
[12] S. E. Diamond, B. Grant, G. M. Tom, H. Taube, Tetrahedron Lett. 15 (1974) 40254028.

[13] (a) S.-I. Murahashi, S. Sasao, E. Saito, T. Naota, J. Org. Chem. 57 (1992) 2521-2523;

(b) S.-I. Murahashi, S. Sasao, E. Saito, T. Naota, Tetrahedron 49 (1993) 8805-8826; (c)

S.-I. Murahashi, T. Naota, Bull. Chem. Soc. Jpn. 69 (1996) 1805-1824; (d) S.-I. Murahashi, H. Takaya, Acc. Chem. Res. 33 (2000) 225-233.

[14] The ability of complex $\left[\mathrm{RuH}_{2}\left(\mathrm{PPh}_{3}\right)_{4}\right]$ to promote the addition of alcohols and amines to nitriles has also been described. See, for example: (a) S.-I. Murahashi, T. Naota, E. Saito, J. Am. Chem. Soc. 108 (1986) 7846-7847; (b) T. Naota, Y. Shichijo, S.-I. Murahashi, J. Chem. Soc., Chem. Commun. (1994) 1359-1360; (c) A. J. M. van Dijk, T. Heyligen, R. Duchateau, J. Meuldijk, C. E. Koning, Chem. Eur. J. 13 (2007) 76647672; (d) A. J. M. van Dijk, R. Duchateau, E. J. M. Hensen, J. Meuldijk, C. E. Koning, Chem. Eur. J. 13 (2007) 7673-7681.

[15] (a) W. K. Fung, X. Huang, M. L. Man, S. M. Ng, M. Y. Hung, Z. Lin, C. P. Lau, J. Am. Chem. Soc. 125 (2003) 11539-11544; (b) C. P. Lau, S. M. Ng, G. Jia, Z. Lin, Coord. Chem. Rev. 251 (2007) 2223-2237.

[16] See, for example: (a) J. M. O’Connor, C. P. Casey, Chem. Rev. 87 (1987) 307-318; (b) M. J. Calhorda, L. F. Veiros, Coord. Chem. Rev. 185-186 (1999) 37-51; (c) V. Cadierno, J. Díez, M. P. Gamasa, J. Gimeno, E. Lastra, Coord. Chem. Rev. 193-195 (1999) 147-205; (d) D. Zargarian, Coord. Chem. Rev. 233-234 (2002) 157-176.

[17] C. W. Leung, W. Zheng, D. Wang, S. M. Ng, C. H. Yeung, Z. Zhou, Z. Lin, C. P. Lau, Organometallics 26 (2007) 1924-1933.

[18] C. W. Leung, W. Zheng, Z. Zhou, Z. Lin, C. P. Lau, Organometallics 27 (2008) $4957-$ 4969.

[19] Related $N$-imidoylimidato ruthenium(II) complexes had been previously described, but they had not been studied in catalysis: K. Hiraki, Y. Kinoshita, J. KinoshitaKawashima, H. Kawano, J. Chem. Soc., Dalton Trans. (1996) 291-298.

[20] C. S. Yi, T. N. Zeczycki, S. V. Lindeman, Organometallics 27 (2008) 2030-2035.

[21] T. Li, I. Bergner, F. N. Haque, M. Zimmer-De Iuliis, D. Song, R. H. Morris, Organometallics 26 (2007) 5940-5949.

[22] (a) M. Utsunomiya, K. Takahashi, T. Oshiki, K. Takai, Jpn. Kokai Tokkyo Koho (2004) JP 2004269522; (b) T. Oshiki, H. Yamashita, K. Sawada, M. Utsunomiya, K. Takahashi, K. Takai, Organometallics 24 (2005) 6287-6290; (c) T. Oshiki, K. Takai, 
Jpn. Kokai Tokkyo Koho (2008) JP 2008088153; (d) T. Oshiki, I. Hyodo, A. Ishizuka, J. Synth. Org. Chem. Jpn. 68 (2010) 41-51.

[23] For leading accounts and reviews on bifunctional catalysts, see: (a) D. B. Grotjahn, Chem. Eur. J. 11 (2005) 7146-7153; (b) A. S. Borovik, Acc. Chem. Res. 38 (2005) 5461; (c) T. Ikariya, K. Murata, R. Noyori, Org. Biomol. Chem. 4 (2006) 393-406; (d) T. Ikariya, A. J. Blacker, Acc. Chem. Res. 40 (2007) 1300-1308; (e) D. B. Grotjahn, Dalton Trans. (2008) 6497-6508; (f) D. B. Grotjahn, Chem. Lett. 39 (2010) 908-914; (g) D. B. Grotjahn, Pure Appl. Chem. 82 (2010) 635-647; (h) T. Ikariya, I. D. Gridnev, Top. Catal. 53 (2010) 894-901; (i) D. B. Grotjahn, Top. Catal. 53 (2010) 1009-1014.

[24] M. Muranaka, I. Hyodo, W. Okumura, T. Oshiki, Catal. Today 164 (2011) 552-555.

[25] T. Šmejkal, B. Breit, Organometallics 26 (2007) 2461-2464.

[26] R. García-Álvarez, S. E. García-Garrido, J. Díez, P. Crochet, V. Cadierno, Eur. J. Inorg. Chem. (2012) 4218-4230.

[27] More recent studies have shown the high lability of $\mathrm{PPh}_{2}$ (py-6-tert-amyl) in complexes 15-16, which can be partially displaced from the ruthenium coordination sphere even by the weak donor ligand dimethyl sulfide. Consequently, decoordination of the pyridyl-phosphine $\mathrm{PPh}_{2}$ (py-6-tert-amyl) during catalysis may also be responsible of the low catalytic activities observed for 15-16: E. Tomás-Mendivil, R. García-Álvarez, S. E. García-Garrido, J. Díez, P. Crochet, V. Cadierno, J. Organomet. Chem. 727 (2013) $1-9$.

[28] R. García-Álvarez, J. Díez, P. Crochet, V. Cadierno, Organometallics 29 (2010) 39553965.

[29] For reviews covering the chemistry of these water-soluble phosphines, see: (a) A. D. Phillips, L. Gonsalvi, A. Romerosa, F. Vizza, M. Peruzzini, Coord. Chem. Rev. 248 (2004) 955-993; (b) K. H. Shaughnessy, Chem. Rev. 109 (2009) 643-710; (c) J. Bravo, S. Bolaño, L. Gonsalvi, M. Peruzzini, Coord. Chem. Rev. 254 (2010) 555-607; (d) M. Zablocka, A. Hameau, A.-M. Caminade, J.-P. Majoral, Adv. Synth. Catal. 352 (2010) 2341-2358; (e) L. Gonsalvi, M. Peruzzini, Catalysis by Metal Complexes 37 (2011) $183-212$.

[30] V. Cadierno, J. Francos, J. Gimeno, Chem. Eur. J. 14 (2008) 6601-6605.

[31] V. Cadierno, J. Díez, J. Francos, J. Gimeno, Chem. Eur. J. 16 (2010) 9808-9817.

[32] A. Cavarzan, A. Scarso, G. Strukul, Green Chem. 12 (2010) 790-794.

[33] S. M. Ashraf, I. Berger, A. A. Nazarov, C. G. Hartinger, M. P. Koroteev, E. E. Nifant'ev, B. K. Keppler, Chem. Biodiversity 5 (2008) 1640-1644. 
[34] A. E. Díaz-Álvarez, R. García-Álvarez, P. Crochet, V. Cadierno, in M. D. S. Silva, P. C. Ferreira (Eds.), Glycerol: Production, Structure and Applications, Nova Science Publishers, New York, 2012, pp. 249-261.

[35] For reviews on the utility of this green solvent for stoichiometric and catalytic organic synthesis, see: (a) Y. Gu, F. Jérôme, Green Chem. 12 (2010) 1127-1138; (b) A. E. Díaz-Álvarez, J. Francos, B. Lastra-Barreira, P. Crochet, V. Cadierno, Chem. Commun. 47 (2011) 6208-6227; (c) A. Wolfson, C. Dlugy, D. Tavor, Trends Org. Chem. 15 (2011) 41-50; (d) V. Calvino-Casilda, in A. Mohammad, Inamuddin (Eds.), Green Solvents I: Properties and Applications, Springer, Dordrecht, 2012, pp.187-207; (e) Y. Gu, F. Jérôme, Chem. Soc. Rev. (2013) in press (DOI: 10.1039/c3cs60241a); (f) A. E. Díaz-Álvarez, J. Francos, P. Crochet, V. Cadierno, Curr. Green Chem. (2014) in press.

[36] Í. Ferrer, J. Rich, X. Fontrodona, M. Rodríguez, I. Romero, Dalton Trans. 42 (2013) 13461-13469.

[37] (a) W.-C. Lee, B. J. Frost, Green Chem. 14 (2012) 62-66; (b) B. J. Frost, W.-C. Lee, US Pat. Appl. (2013) US 20130096344.

[38] W.-C. Lee, J. M. Sears, R. A. Enow, K. Eads, D. A. Krogstad, B. J. Frost, Inorg. Chem. 52 (2013) 1737-1746.

[39] R. García-Álvarez, M. Zablocka, P. Crochet, C. Duhayon, J.-P. Majoral, V. Cadierno, Green Chem. 15 (2013) 2447-2456.

[40] (a) R. García-Álvarez, J. Francos, P. Crochet, V. Cadierno, Tetrahedron Lett. 52 (2011) 4218-4220; (b) R. García-Álvarez, J. Díez, P. Crochet, V. Cadierno, Organometallics 30 (2011) 5442-5451.

[41] Complex $\left[\mathrm{RuCl}_{2}\left(\eta^{6}-\mathrm{C}_{6} \mathrm{Me}_{6}\right)\left\{\mathrm{P}\left(\mathrm{NMe}_{2}\right)_{3}\right\}\right]$ (27) has also proven to be a highly effective catalyst for primary amides formation by rearrangement of aldoximes and direct coupling of aldehydes with hydroxylamine in water: (a) R. García-Álvarez, A. E. DíazÁlvarez, J. Borge, P. Crochet, V. Cadierno, Organometallics 31 (2012) 6482-6490; (b) R. García-Álvarez, A. E. Díaz-Álvarez, P. Crochet, V. Cadierno, RSC Adv. 3 (2013) 5889-5894.

[42] (a) S. M. M. Knapp, T. J. Sherbow, J. J. Juliette, D. R. Tyler, Organometallics 31 (2012) 2941-2944; (b) S. M. M. Knapp, T. J. Sherbow, R. B. Yelle, L. N. Zakharov, J. J. Juliette, D. R. Tyler, Organometallics 32 (2013) 824-834.

[43] (a) A. Papakyprianou, A. W. Parkins, P. D. Prince, J. W. Steed, Org. Prep. Proced. Int. 34 (2002) 436-440; (b) T. J. Ahmed, B. R. Fox, S. M. M. Knapp, R. B. Yelle, J. J. 
Juliette, D. R. Tyler, Inorg. Chem. 48 (2009) 7828-7837; (c) S. M. M. Knapp, T. J. Sherbow, T. J. Ahmed, I. Thiel, L. N. Zakharov, J. J. Juliette, D. R. Tyler, J. Inorg. Organomet. Polym. (2013) in press (DOI: 10.1007/s10904-013-9957-z).

[44] S. M. M. Knapp, T. J. Sherbow, R. B. Yelle, J. J. Juliette, D. R. Tyler, Organometallics 32 (2013) 3744-3752.

[45] The utility of similar $\left[\mathrm{RuX}_{2}\left(\eta^{6}\right.\right.$-arene) $\left.\left\{\mathrm{PR}_{2}(\mathrm{OH})\right\}\right]$ (arene $=\mathrm{C}_{6} \mathrm{H}_{6}, p$-cymene, $\mathrm{C}_{6} \mathrm{Me}_{6} ; \mathrm{X}$ $=\mathrm{Cl}, \mathrm{Br}, \mathrm{I} ; \mathrm{R}=\mathrm{Ph},{ }^{\mathrm{n}} \mathrm{Bu}$; not all combinations) complexes for nitrile hydration reactions has been the subject of a patent: T. Oshiki, M. Muranaka, PCT Int. Appl. (2012) WO 2012/017966.

[46] H. B. Ammar, X. Miao, C. Fischmeister, L. Toupet, P. H. Dixneuf, Organometallics 29 (2010) 4234-4238.

[47] S. M. Ashraf, W. Kandioller, M.-G. Mendoza-Ferri, A. A. Nazarov, C. G. Hartinger, B. K. Keppler, Chem. Biodiversity 5 (2008) 2060-2066.

[48] See, for example: I. N. Stepanenko, B. Cebrián-Losantos, V. B. Arion, A. A. Krokhin, A. A. Nazarov, B. K. Keppler, Eur. J. Inorg. Chem. (2007) 400-411 and references cited therein.

[49] S. Kamezaki, S. Akiyama, Y. Kayaki, S. Kuwata, T. Ikariya, Tetrahedron: Asymmetry 21 (2010) 1169-1172.

[50] M. Martín, H. Horváth, E. Sola, Á. Kathó, F. Joó, Organometallics 28 (2009) 561-566.

[51] One of the mechanisms usually evoked in the literature for metal-catalyzed nitrile hydration reactions involves the nucleophilic attack of a hydroxide ligand to the carbon atom of the coordinated nitrile to afford a $\kappa^{2}$-amidate intermediate, which subsequently undergoes water addition to give the amide and regenerate the $\mathrm{M}-\mathrm{OH}$ catalyst. For selected examples, see: (a) K. L. Breno, M. D. Pluth, D. R. Tyler, Organometallics 22 (2003) 1203-1211; (b) E. Tílvez, M. I. Menéndez, R. López, Organometallics 31 (2012) 1618-1626; (c) M. L. Buil, V. Cadierno, M. A. Esteruelas, J. Gimeno, J. Herrero, S. Izquierdo, E. Oñate, Organometallics 31 (2012) 6861-6867.

[52] D. Kumar, C. A. Masitas, T. N. Nguyen, C. A. Grapperhaus, Chem. Commun. 49 (2013) 294-296.

[53] T. Kurata, A. Tamuro, Y. Murata, S. Nagashima, T. Okano, K. Ohfuchi, Jpn. Kokai Tokkyo Koho (1973) JP 48054021.

[54] T. Mizuno, Jpn. Kokai Tokkyo Koho (2005) JP 2005170821.

[55] T. Oshiki, A. Ishizuka, Jpn. Kokai Tokkyo Koho (2009) JP 2009214099.

[56] S. Kumar, P. Das, New J. Chem. 37 (2013) 2987-2990. 
[57] G. K. S. Prakash, S. B. Munoz, A. Papp, K. Masood, I. Bychinskaya, T. Mathew, G. A. Olah, Asian J. Org. Chem. 1 (2012) 146-149.

[58] (a) K. Yamaguchi, M. Matsushita, N. Mizuno, Angew. Chem. Int. Ed. 43 (2004) 15761580; (b) K. Yamaguchi, N. Mizuno, Synlett (2010) 2365-2382.

[59] J. W. Kim, K. Yamaguchi, N. Mizuno, Angew. Chem. Int. Ed. 47 (2008) 9249-9251.

[60] J. He, K. Yamaguchi, N. Mizuno, J. Org. Chem. 76 (2011) 4606-4610.

[61] (a) V. Polshettiwar, R. S. Varma, Chem. Eur. J. 15 (2009) 1582-1586; (b) R. B. N. Baig, R. S. Varma, Green Chem. 15 (2013) 398-417.

[62] R. B. N. Baig, R. S. Varma, Chem. Commun. 48 (2012) 6220-6222.

[63] S. E. García-Garrido, J. Francos, V. Cadierno, J.-M. Basset, V. Polshettiwar, ChemSusChem 4 (2011) 104-111.

[64] K. Mori, K. Yamaguchi, T. Mizugaki, K. Ebitani, K. Kaneda, Chem. Commun. (2001) 461-462. 
FOR GRAPHICAL ABSTRACT USE ONLY

\title{
Metal-catalyzed nitrile hydration reactions: The specific contribution of ruthenium
}

\author{
Rocío García-Álvarez, Javier Francos, E. Tomás-Mendivil, Pascale Crochet and Victorio \\ Cadierno*
}

In this review article, a comprehensive account of the application of ruthenium-based catalysts for the selective hydration of nitriles to amides is presented. Both homogeneous and heterogeneous systems are discussed.

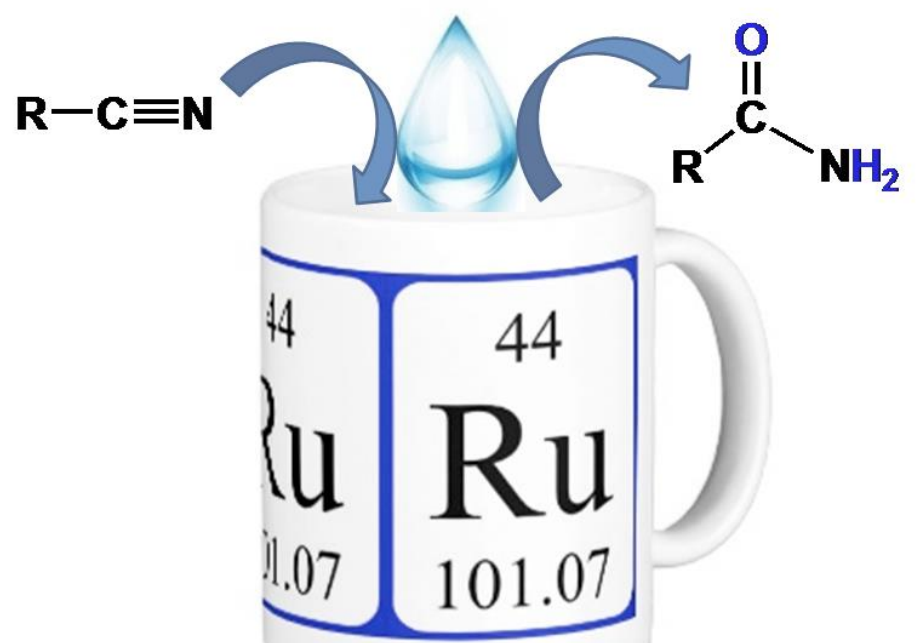




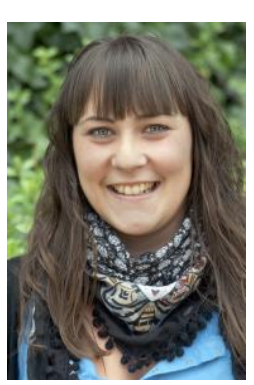

Rocío García-Álvarez received her BSc in Chemistry from the University of Oviedo in 2007. In 2013 she obtained her $\mathrm{PhD}$ degree working under the supervision of Drs. P. Crochet and V. Cadierno at the University of Oviedo, with research on novel ruthenium catalysts for amide-bond forming reactions in environmentally friendly aqueous media.

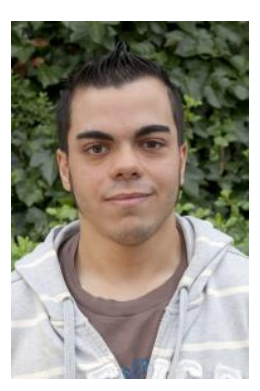

Javier Francos studied chemistry at the University of Oviedo and obtained his $\mathrm{PhD}$ in 2011 under the supervision of Prof. J. Gimeno and Dr. V. Cadierno working on the catalytic applications of ruthenium complexes in water. He then then joined the group of Prof. J. L. Mascareñas at the University of Santiago de Compostela (Spain) for a one-year postdoctoral stay, and since June 2012 is working as a research fellow at the University of Strathclyde (U.K.) under the supervision of Dr. Charles O’Hara.

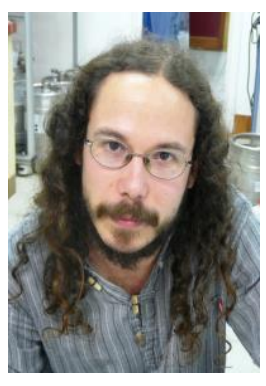

Eder Tomás-Mendivil received his BSc in chemistry at the Universidad del País Vasco/Euskal Herriko Unibertsitatea in 2009. After an ERASMUS internship at the University of Utrecht working in the group of Prof. R. J. M. Klein Gebbink (2008/2009) he moved to the University of Oviedo to begin his $\mathrm{PhD}$ under the supervision of Dr. V. Cadierno. His research is focused on the synthesis of new transition metal complexes for catalytic applications in aqueous media.



Pascale Crochet studied chemistry at the University of Rennes I (France) and obtained her PhD in 1996 under the supervision of Prof. P. H. Dixneuf and B. Demerseman. After a two-year post-doctoral stay in the group of Prof. M. A. Esteruelas (University of Zaragoza, Spain) and one year as Assistant Professor at the "National High School of Physics and Chemistry" of Bordeaux (France), she moved in 1999 to the University of Oviedo where she is currently Associate Professor of Inorganic Chemistry. Her research interests deal with the design and synthetic applications of organometallic complexes, with a particular focus on hydrosoluble ruthenium catalysts. 


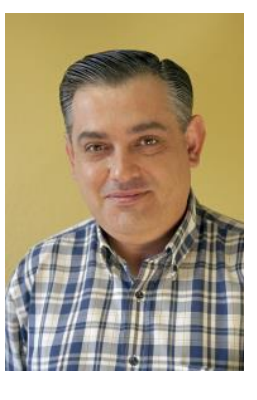

Victorio Cadierno received his $\mathrm{PhD}$ degree from the University of Oviedo (Spain) in 1996 under the supervision of Prof. J. Gimeno. He then joined the group of Dr. J. P. Majoral at the Laboratoire de Chimie de Coordination (LCC-CNRS) in Toulouse (France) for a two-years postdoctoral stay. Thereafter, he returned to the University of Oviedo where he is currently Associate Professor of Inorganic Chemistry. His research involves the use of transition metal complexes for catalytic organic synthesis, with special focus in ruthenium chemistry. 